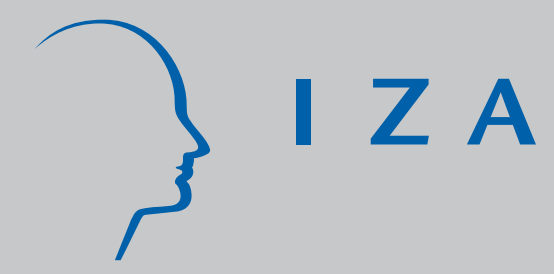

IZA DP No. 562

\title{
Changes in Collective Bargaining in the U.K.
}

J ohn T. Addison

W. Stanley Siebert

August 2002 


\title{
Changes in Collective Bargaining in the U.K.
}

\author{
John T. Addison \\ University of South Carolina and IZA Bonn \\ W. Stanley Siebert \\ University of Birmingham, UK
}

Discussion Paper No. 562

August 2002

\author{
IZA \\ P.O. Box 7240 \\ D-53072 Bonn \\ Germany \\ Tel.: +49-228-3894-0 \\ Fax: +49-228-3894-210 \\ Email: iza@iza.org
}

This Discussion Paper is issued within the framework of IZA's research area Welfare State and Labor Market. Any opinions expressed here are those of the author(s) and not those of the institute. Research disseminated by IZA may include views on policy, but the institute itself takes no institutional policy positions.

The Institute for the Study of Labor (IZA) in Bonn is a local and virtual international research center and a place of communication between science, politics and business. IZA is an independent, nonprofit limited liability company (Gesellschaft mit beschränkter Haftung) supported by the Deutsche Post AG. The center is associated with the University of Bonn and offers a stimulating research environment through its research networks, research support, and visitors and doctoral programs. IZA engages in (i) original and internationally competitive research in all fields of labor economics, (ii) development of policy concepts, and (iii) dissemination of research results and concepts to the interested public. The current research program deals with (1) mobility and flexibility of labor, (2) internationalization of labor markets, (3) welfare state and labor market, (4) labor markets in transition countries, (5) the future of labor, (6) evaluation of labor market policies and projects and (7) general labor economics.

IZA Discussion Papers often represent preliminary work and are circulated to encourage discussion. Citation of such a paper should account for its provisional character. A revised version may be available on the IZA website (www.iza.org) or directly from the author. 
IZA Discussion Paper No. 562

August 2002

\section{ABSTRACT}

\section{Changes in Collective Bargaining in the U.K.}

Perhaps no other country in recent years has witnessed greater change in its collective bargaining framework than the UK. This paper describes the dramatic developments and their consequences. Like Gaul, it is in three parts. The first part charts the six major pieces of legislation - conventionally described as 'anti-union' - that were enacted by successive Conservative administrations between 1980 and 1993, and links them to the subsequent decline in unionism and to improvements in firm performance and that of the macro economy. The second part examines the accession of 'New Labour' and reviews its domestic reform agenda, today largely in place. That agenda comprises two general pieces of employment and employment relations law plus a new national minimum wage. At first (and second) blush these changes do not return Britain to the mid-1970s even if they do imply an increase in union membership and rising costs for business. For evidence of more profound change one has to turn to the third part of our story: the social policy agenda of the European Union. Almost immediately upon taking office, New Labour signed up to the social chapter. This means that a slew of new legislation seeking to regulate the employment relation (mostly decided by qualified majority) is now in immediate prospect. Europe is therefore set to impact the theory and practice of British industrial relations. We provide a brief review of recent and prospective legislation.

JEL Classification: K31, J31, J51, J53, J58, J81, J83, J88

Keywords: $\quad$ union legislation, Thatcher, New Labour, EU social policy

John T. Addison

Department of Economics

University of South Carolina

Columbia, SC 29208

USA

Tel.: +1-803-777-4608

Fax: +1-803-777-6876

Email: ecceaddi@darla.badm.sc.edu

\footnotetext{
* This essay will appear as Chapter 13 in John T. Addison and Claus Schnabel (eds.) The International
} Handbook of Trade Unions, Cheltenham: Edward Elgar, 2003. 
'There will be no going back. The days of strikes without ballots, mass picketing, closed shops and secondary action are over' (Tony Blair, May 1998; see Department of Trade and Industry, 1998, p. 3).

'I see trade unions as a force for good, an essential part of our democracy, but as more than that, potentially, as a force for economic success. They are a part of the solution to achieving business success and not an obstacle to it' (Tony Blair, September 1999; see Brown, 2000, p. 305).

\section{Introduction}

In this chapter we investigate the major changes that have taken place in collective bargaining in the UK in the last two decades, consider their impact, and further address the consequences of union decline. We shall also speculate on the likely course of bargaining arrangements over the first decade of the present century. Much attention will be given over to the ever-changing legal framework within which collective bargaining is set - swings in the legal pendulum from Thatcher through Blair to, potentially much more important, the ministrations of the European Union (EU).

Domestic and international law provide the backbone of our discussion. We will review the main legislative enactments of the Thatcher/Major administrations introduced between 1980-93. We also describe at more leisurely pace the changes engineered by New Labour in the form of the 1999 Employment Relations Act and the prospective Employment Bill. At issue is whether these most recent domestically initiated changes in the law are reversals of the status quo ante or tidying up exercises, especially on the equity front. Be that as it may, EU social policy initiatives portend more dramatic changes - and more so for Britain than other member states of the Community.

The extensive nature of the legal changes introduced between 1980 and 1993 has been linked to shifts in the impact of unions on various dimensions of firm performance, as well as the union premium and wage inequality. We review these outcomes. There has also occurred some material improvement in Britain's comparative economic performance, which we also chart. In each case, it is conventional - and in our view correct - to attribute these largely beneficial changes in part to innovations in union law. As usual, however, the devil is in the detail and it would be idle to pretend that we can apportion the component contributions of legislation, deregulation, and globalisation. 
If domestic legislation were the end of the story, then an economic evaluation of post-1997 developments would focus on indicative cost estimates of a modest number of changes, some of which are nontrivial. But one of the first actions of the new administration when it came into office was to sign up to the social charter. The social policy agenda of the EU has deep-seated implications for collective bargaining in Britain, so that we have also to address in more detail and perhaps give equal billing to the 'economic consequences of Mr. Blair' as we do to Mrs. Thatcher.

\section{The Thatcher reforms}

\section{Legislation $^{1}$}

A summary of the laws affecting unionism introduced by Mrs. Thatcher and her successors is given in Table 1. To give context, the table actually starts with some Old Labour legislation in the form of the 1974 Trade Union and Labour Relations Act (TULRA) (amended in 1976). ${ }^{2}$ This distinctly pro-union legislation was the quid pro quo for union agreement on a voluntary incomes policy. Both TULRA and the Employment Protection Act of 1975 used the concept of unfair dismissal (see footnote 1) to strengthen the closed shop or union membership agreements (UMAs). This was achieved by removing employment protection from workers who were dismissed for not belonging to a union in workplaces where union membership was a condition of employment. In other words, dismissal for non-membership of a union was 'fair' when a firm had a closed shop. This innovation led to the expansion of closed shop to almost 5 million workers in 1980, mainly of the "post-entry" variety.

(Table 1 near here)

The 1975 Employment Protection Act put in place further measures to 'encourage the extension of collective bargaining'. First, unions were given the right to claim arbitration from the Central Arbitration Committee (CAC) to secure the observance of 'recognized' terms and conditions of employment in an industry. If the CAC identified an employer as engaged in an industry covered by an industry-wide agreement, it could make an award bringing that employer's terms and conditions up to the recognized level. Also under this so-called 'Schedule 11' procedure, in the absence of such terms unions could claim arbitration to apply the 'general level' obtaining for comparable workers in the district. ${ }^{3}$ Second, the Act also provided that of the Advisory, Conciliation and 
Arbitration Service (ACAS) could be called on by a union to make a recommendation that it be recognized by an employer for collective bargaining purposes. Failure on the part of the employer to comply involved the possibility of an arbitration award by the CAC. Overall, ACAS heard about 1,600 union claims for recognition over the period 1976-1980, when the procedure was operative (ending with the 1980 Employment Act), and has estimated that its efforts resulted in the extension of recognition to about 65,000 workers (ACAS, 1981, p. 99). Although this might seem a small number in the national context, the procedure helped union organising activities by establishing that public policy was favourable to union organisation and in encouraging employers to recognise unions voluntarily to avoid the public scrutiny involving a reference to ACAS (Davies and Freedland, 1993, p. 421).

One of the election pledges of the incoming Conservative government of Mrs. Thatcher in 1979 was root and branch union reform. Indeed, successive Conservative administrations passed six important pieces of industrial relations legislation, 1980-93. ${ }^{4}$ But at the beginning Conservative governments felt the need to move cautiously. Under the first piece of legislation, the 1980 Employment Act, only new UMAs were submitted to a tough electoral hurdle of an 80 per cent majority (existing UMAs were left untouched). At the same time, strike threat power was reduced by removing union immunity from liability for damages when organizing 'secondary' strikes, including coercive union recruitment campaigns "blacking" the goods of nonunion firms. For the moment, however, the union itself - and in particular union funds - broadly remained immune from all actions for damages. The Act also introduced the idea of secret ballots, which at this stage were only voluntary. A fund was established from which trade unions could be reimbursed for expenditures in connection with such postal ballots. The TUC response was to boycott the scheme. Finally, the legislation abolished statutory union recognition procedures.

The 1982 Employment Act was much bolder. All UMAs were now required to clear the voting hurdle every five years. Dismissal for non-membership of a union where there was an existing UMA remained lawful, but only if the UMA had secured the necessary majority within the previous five years. Punitive compensation of up to $£ 26,800$ was available for individuals adjudged wrongfully dismissed (Deakin and 
Morris, 1995, p. 445). Measures were also adopted to stop discrimination against nonunion workers: Contracts could not be enforced if they specified union-only labour, nor could tenders be awarded on this basis. Relatedly, the Fair Wages resolution was also rescinded. ${ }^{5}$

The 1982 Act also removed trade unions' blanket immunity from liability for damages for actions in tort. Specifically, the legislation reduced the number of torts for which immunity was given by narrowing the definition of a trade dispute. Moreover, unions would be liable for industrial action left unprotected by the more limited immunities. Prior to the Act, the only real remedy for employers was against individual dispute organisers, who would not have the wherewithal to pay substantial damages. Henceforth, the union could be sued for unlawful industrial action - although given the large possible damages to which unions could be exposed, the Act placed an upper limit on damages that could be awarded against unions.

In the wake of the 1982 Act, there was to be a steady increase in legal actions by employers against unions (McKay, 1996) - and also against striking workers. Most legal challenges took the form of the interlocutory injunction; that is, a court order to prevent the onset or continuation of industrial action, issued at the discretion of the High Court pending a full trial. (Note such remedies are precluded as unfair in the US.) The alternative to the injunction is the action for damages, which was hardly considered before the 1982 Act for the reasons given earlier. By contrast, between 1980 and 1995 there were 201 legal actions against unions, including 166 injunctions (McKay, 1996, pp. $11,14)$.

Following the re-election of Mrs. Thatcher in 1983, an enduring legislative innovation was the 1984 Trade Union Act. The legislation developed the balloting idea presaged in the 1982 Act. Secret ballots were now required in three areas: before industrial action, when electing union officials, and for the political levy. Without a ballot, trade union immunity was lost. Such ballots impeded industrial action because the rules were 'extremely complex, technical and, in parts, ambiguous, thus leaving unions vulnerable to potential challenge in the courts on several counts' (Deakin and Morris, 1995, p. 794). The Act and its associated Code of Practice put forward principles governing such matters as the balloting constituency, content of the voting paper, conduct 
of the ballot, and the time limit ( 4 weeks) within which action had to be taken after a ballot. Approximately one-third of the injunctions taken out since 1980 were based on these balloting provisions (McKay, 1996, p. 16). ${ }^{6}$

In 1988 and 1990 two further Employment Acts were passed. The 1988 Employment Act followed another election victory for Mrs. Thatcher, after a campaign in which the issue of union power had again figured large. This Act sought to remove the ability of trade unions to enforce the closed shop through industrial action. It thus became unlawful to take any form of industrial action to establish or maintain a closed shop, irrespective of whether or not the closed shop had been approved in a ballot. It was now also unfair to dismiss an employee for non-membership in a union, even if that arrangement had been sanctioned by ballot. The legislation also made it 'unjustifiable' for unions to discipline members for refusing to take part in industrial action. The courts were empowered to award up to $£ 30,000$ for such infringements (the same amount as obtained in the case of unjustifiable expulsion from a union). For the first time, union members could also take their union to court on the grounds that industrial action had not been the subject of a lawful ballot.

The 1990 Employment Act then tried a different approach to the closed shop. Hitherto the legislative attack had attempted to eliminate the threat of dismissal based on non-membership. Now attention turned to the point of hire. The Act made it unlawful to discriminate against nonunion workers when hiring. By the same token, it was also unlawful to discriminate against union workers when hiring, although employers were entitled to protect themselves against troublemakers. In each case the aggrieved job applicant had to make a complaint to an Industrial Tribunal. A closed-shop agreement, oddly enough, was not in and of itself unlawful (Hendy, 1993, p. 65). The 1990 legislation further circumscribed strike activity by holding unions liable for unofficial action unless that was expressly repudiated. Unofficial strikers could be summarily dismissed by their employers, and any action taken on behalf of these workers lost immunity. Finally, all secondary action was outlawed.

The last piece of Conservative union legislation was the 1993 Trade Union Reform and Employment Rights Act, which again followed an election victory albeit sans Thatcher. The Act's most far-reaching change for unions was its requirement for written 
authorization from union members for the dues check-off every three years. The Act also stipulated that an individual would be free to join any union at the workplace. This clause sought to over-ride trade union procedures preventing unions poaching members from each other (the Bridlington rules). It was felt that the measure would also weaken union control over particular jobs, and thereby lead to increased flexibility at the workplace. In addition to these changes, the legislation tightened balloting rules for industrial action, most notably with respect to the obligation to notify employees. It also abolished Wages Councils.

Against this backdrop, the election of New Labour in 1997 was inevitably to bring about another policy shift. Yet, as Table 1 indicates, its major piece of legislation was not to be enacted for another two years. In the interstices, the new government was only to nibble at the edges as it were; for example, by repealing in 1998 the requirement that the union obtain written authorisation from its members for the check-off every three years. We consider New Labour's approach record after reviewing the economic consequences of the Tory reforms, 1980-93.

\section{Economic Effects}

Even though we shall subsequently have occasion to go behind the following numbers, perhaps the most obvious development on the union front in Britain has been the pronounced decline in unionism in the last two decades - this after a period of substantial growth. In 1979 some 53 per cent of workers were union members. By 1999 this had fallen to 28 per cent. Correspondingly, there has also occurred a sharp fall in the share of employees whose wages are set by collective bargaining: from 70 per cent in 1980 to around 45 percent in the mid-1990s (see Machin, 2000).

There are a number of explanations for this overall tendency, including the changing structure of the economy and the workforce (and collective bargaining), macroeconomic developments, increased competitiveness, and changes in union organizing activities. It seems that we can downgrade the importance of compositional factors (such as increases in the proportion of female workers) many of which also applied in the 1970s when unions were growing apace. As for macroeconomic factors, and in particular the business cycle (see Chapter 2 of this volume), these have undoubtedly played a role but in all likelihood a secondary one. This is because the 
downturn in union recognition reflects an inability of unions to organize new establishments that have been set up since 1980 rather than a process of derecognition (Disney et al., 1995; Machin, 2000). The issue then devolves on why this process of recognition has become more difficult. Freeman and Pelletier's (1990) business cycle model accords the law pride of place, arguing that virtually all of the change in union density, 1980-86, is due to the strictures of British industrial relations legislation. This is probably going too far because some other countries have experienced precipitous declines in union membership without corresponding changes in their legal environment. On the other hand, the decline in coverage in Britain is anomalous and as we have seen the purchase of the law is direct here. Moreover, once we view the changes in union law as part of a wider reform agenda, the contribution of the law is central and not easily dismissed as permissive.

Turning therefore to the questions of the economic consequences of the decline in unionism, we first review the evidence of union effects on performance at establishment level through time - along the dimensions of productivity and productivity growth, profitability, pay, employment, and plant closings - before examining changes in Britain's macroeconomic performance. Perhaps no micro outcome indicator has attracted greater scrutiny than establishment and firm productivity. The early literature points to negative union effects despite contemporaneous estimates of the union-nonunion pay differential of 10 per cent (see Machin, 1991). The dominant theme of studies using more recent data, however, is that unionized firms/plants increased their productivity most at the end of the 1980s (and perhaps also in 1979-84) and/or that there is no longer evidence of a union productivity shortfall (see, for example, Gregg et al., 1993; Conyon and Freeman, 2001; Moreton, 1999; Fernie and Metcalf, 1995; and Addison and Belfield, 2001.) But the latter evidence is not overwhelming, leaving us with the more attenuated conclusion is that there has been a reduction in the 'disadvantages of unionism' (Oulton, 1990, p. 5) through time. At issue here, apart from the suggestion that inefficient union plants have been evoluted out of the system, is whether negative union effects are confined to establishments where there is fragmented bargaining (a regime in which multiple unions bargaining separately) (Pencavel, 2001) and whether negative effects can be overturned in a supportive industrial relations environment (Brown et al., 1997; 
Metcalf, Chapter 5 this volume).

The early evidence concerning unions and profitability/financial performance points unequivocally to lower profits in unionized workplaces (see, for example, the survey by Metcalf, 1993). The more recent evidence presents a more mixed picture although there is every indication of a decline - even a 'collapse' - in this effect through time (see, in particular, Machin and Stewart, 1996; Menezes-Filho, 1997; Addison and Belfield, 2001). There is thus some disputation as to whether the union effect is still negative and continuing controversy as to the implications of a negative coefficient estimate for the union variable where observed. In the former case, Pencavel (2001) reports that any reduction in financial performance is confined to situations where bargaining is fragmented (but see Menezes-Filho, 1997). This result is in some sense the "successor" to the hierarchy of union effect observed in earlier data, where stronger adverse profitability effects were observed in closed shop settings or where management recommended unionism to its workers. In the latter case, since there is more evidence for the UK than for the US that union wage gains come at the expense of excess profits (rather than normal returns), there has been less concern with allocative consequences (see also Chapter 10 of this volume).

The trend of the profitability findings is also consistent with some evidence on the development of the union wage mark up. Thus, studies using workplace data point to a decline in the union premium during the decade of the 1990s after a period of stability (see Stewart, 1987, 1995). Also, the most recent workplace data for 1998 indicate a further diminution of the union premium (see, for example, Bryson, 2002). On the other hand, work using individual data indicates much greater persistence in the union markup even if not in the number of workers in receipt of it! Thus, we cannot conclude from the data that the wage premium has withered away. Rather, the indication is that if the reform agenda ushered in a material reduction in the union non-union differential it was long in coming (see Chapter 7 of this volume).

We next consider the effects of unions on employment. Here the key research finding from workplace data is a consistently negative effect of unions on employment, with no real suggestion of any moderation in that effect over time (an exception is the study by Millward et al., 1992). Unions thus seem to retard employment growth. A rule 
of thumb is that unionised establishments tend to grow by roughly 3 per cent less per year than their non-unionised counterparts (e.g. Blanchflower et al., 1991; Booth and McCulloch, 1999).

There was some concern in the early literature that the union employment effect at this time (1980-84) was simply the result of an abandonment of restrictive practices in the union sector. In other words, the reduction in employment in the union sector might be a one-time affair followed by normal employment growth after some interval in which changes in working conditions had been fully digested. This suspicion gained currency because the union coefficient in the employment change equation of Blanchflower et al. (1991) was found to be sensitive to the inclusion of a variable identifying 'organizational change' at the workplace, a proxy for any such reform of working conditions (see Machin and Wadhwani, 1991). However, in addressing this very problem, Blanchflower et al. report that their union result stands when the union density measure is replaced by union recognition, and that in any event their results for union density also hold up once one splits the sample according to whether or not plants experienced organizational change. Also, as noted, research using more recent data further attests to the robustness of the union employment result in the presence of organizational change, and the negative effect is replicated in panel data (Addison and Belfield, 2002b). Here, then, is one empirical regularity.

The final micro outcome indicator we examine is plant closings. The evidence is intriguing in the light of the foregoing. Thus, studies using information on plant closings for 1984-90, linked to union and economic data for 1984, reveal a negative but statistically insignificant association between union recognition and plant closings (Machin, 1995). Moreover, more powerful unions, as proxied by the magnitude of the wage premium or presence of the closed shop, have no incremental effect on closings (Stewart, 1995). But when we come to consider closings data for 1990-98, now linked to union and other information for 1990, the effect of unionism on closings is reversed; that is, the sign of the coefficient estimate for the union variable is now positive and statistically significant (Addison et al., 2001; Bryson, 2001). This broad result hides as much as it reveals. Although reporting a material and robust positive association between either of two measures of unionism - recognition for collective bargaining purposes and 
union coverage - Addison et al. (2001) find that this holds only for establishments that are part of larger (i.e. multi-establishment) undertakings. For single-plant entities (here firms), the direction of the association is reversed. (All studies support the more general result that single independent plants are less likely to close than their counterparts that are part of multi-establishment undertakings.) The authors interpret the former result as consistent with a decline in union bargaining power in the wake of a more than a decade of legislation removing union immunities and regulating union governance, either by emboldening employers in multiplant enterprises to close unionized establishments, or by weakening union influence over employment in such settings (see Manning, 1993). ${ }^{7}$ The single plant result, on the other hand, is rationalized in terms of (differential) union concessions in conjunction with rents.

While not contesting these empirical findings, Bryson (2001) argues that union weakness - presumably accentuated by the legislation - underpins the change in union effect detected in the more recent workplace data. He contends that this development is deleterious - whereas it is implicit in the previous study that the rate of plant closings was earlier suboptimal. For Bryson weak unions are less able to fulfil the collective voice function. ${ }^{8} \mathrm{He}$ reports that where unions are strong the coefficient estimate for unionism in the plant closings probit equation is no longer statistically significant. Strong unions are variously defined by the presence of the closed shop, and a combination of high union density, extensive bargaining coverage, and accompanying on-site lay union representatives, inter al. In short, the converse situation defines unions that are too weak to be an efficient instrument of collective voice for workers. ${ }^{9}$

This concludes our review of the micro evidence. We preface our discussion of comparative macro effects with some remarks on the British strikes record not least since it was the famous 'winter of discontent' that propelled Mrs. Thatcher into office. The facts of the matter are that strikes have decreased by a factor of 10 since 1979: the number of stoppages declined from over 2,000 a year in the 1970s to around 200 a year during most of the 1990s $\mathrm{r}$ of workers involved from 4.61 million to 174,000/ (Employment Department, 1995, Table 2; ONS, 2001, Table 2).

The union legislation detailed in rows 3 through 8 of Table 1 has clearly increased the costs of strikes to unions. Yet these legal challenges to strike action do not 
speak for themselves. For example, one also needs to know the practicalities, such as how the law has been used by employers. Moreover, on theoretical grounds - and in particular from the perspective of Pareto-optimal accident theories - the main effect of the law should presumably have taken the form of reducing settlements by chipping away at union bargaining power rather than affecting strike frequency (Siebert and Addison, 1981; Hirsch and Addison, 1986; Chapter 4 this volume). Strike frequency has more to do with factors associated with incomplete or asymmetric information, and hence with miscalculation on the part of either or both sides as to the position of the other's concession curve. The legislation is not easily diagnosed in these terms, although the undoubted ambiguities as to what constituted lawful industrial action under the evolving law may have caused unions to be overly cautious in exercising their bargaining power. From a different theoretical perspective the changes in the law narrowing the range of (legal) industrial action may have curbed strikes having a basis in solidaristic and political goals.

Empirical analysis has been unable to disentangle the effects of changes in the law from other factors that have likely reduced strikes, such as heightened unemployment, falling union membership, and compositional factors attendant on the decline of sectors with traditionally high levels of strike activity (see Dunn and Metcalf, 1996). Even though there is no firm indication that the legislation reduced strikes at a given unemployment rate (Blanchflower and Freeman, 1994, p. 57), the general presumption is nonetheless that the influence of the law has increased. Not only did legal challenges in the courts increase, but also management was - at least until comparatively recently - encouraged to use an implied threat of legal action.

Two final empirical regularities might usefully be mentioned. Whatever the theoretical pedigree of the argument, the closed shop has been linked empirically to higher strike propensity, so the decline in the closed shop offers one possible explanation for the observed reduction in industrial action. Perhaps more important, in view of the greater robustness of the empirical association, has been the decline in multi-unionism (Millward et al., 1992, p. 282), with the offsetting (mechanical) effect of decentralized bargaining countered by a corresponding growth in single-table bargaining.

The institutional reforms designed to reduce union power were but one 
component of an internally self-consistent reform package adopted by successive Conservative administrations with a view to improving Britain's poor relative economic performance. These measures included, in addition to the abolition exchange controls and statutory wage-fixing machinery (on the wages council component, see below), a sustained program of privatisation of the nationalised (and heavily unionised) industries, the contracting out of government services to private-sector enterprises, the deregulation of once-regulated industries, and welfare reform (although the scale of the reduction in the replacement rate has been overstated). ${ }^{10}$

Comparing the decade of the 1980s with that of the 1970s, data provided by Blanchflower and Freeman (1994) suggest that these reforms may have succeeded in improving the relative position of the U.K. vis-à-vis other OECD nations in terms of inflation, growth, and unit labor costs. The authors also observe some domestic improvement in the speed of employment adjustment and in the responsiveness of wages to local conditions. That said, Blanchflower and Freeman do rather accentuate the negative. Apart from the pronounced rise in wage inequality in Britain during the 1980s (examined in more detail below), they note that the reforms were not associated with any improvement in the responsiveness of real wages to unemployment and even appeared to be accompanied by a relative deterioration in unemployment (for males though not for females).

Given that their sample period is 1979-90, the authors do recognize that the legal measures may not have had time to work. Fortunately, an updated treatment is available in the work of Card and Freeman (2001). The authors first assemble information from reputation indices of economic competitiveness/freedom to illustrate the favourable developing position of the UK. It is shown that, at the start of Mrs. Thatcher's period in office, Britain occupied a middling rank among OECD countries in terms of the market friendliness of its institutions, but by the end of the 1990s it stood at the top of the rankings. In similar vein, the authors also examine cross-country rankings of labour market institutions - extent of unionisation, centralisation of bargaining, and employment protection legislation - and again report the tendency towards greater market orientation of such institutions in Britain.

Next the authors examine trends in GDP per capita (here, per working age adult) 
for the UK, France and Germany (and the US), 1960-99, and its decomposition into output per unit of labour and labour input per working age adult. It is shown that after 1979 British output per working age adult grew at a faster rate than in either Germany or France, in sharp contrast to the two decades before then. This turnaround largely reflected rising labor input per capita in Britain, that is, increasing labour force participation (and hours). After 1980 labour productivity (i.e. output per unit of labour input) in the UK grew at approximately the same rate in Britain as in Germany and France unlike in earlier years when British productivity lagged. Interestingly, the poor productivity record of the UK prior to 1979 does not represent "inadequate" investment, and after 1979 capital again grew at much the same rates in the three European countries. After controlling for the contributions of sectoral shifts and capital, there remains an unexplained growth in UK output per capita and output per working age adult vis-à-vis Germany and France.

In other words, British labour productivity and labour force participation rose independently of sectoral shifts and investment propensities in the interval of the Thatcher reform years relative to that country's chief European competitors. Why? Using estimates of the lower productivity of union workers in Britain before 1979, and an assumed elimination of that differential thereafter, Card and Freeman calculate that up to 4.3 percentage points of the gain in productivity (somewhat over one-eighth of the total) can be attributed to the union reforms. They also estimate that two other reforms, privatisation and the introduction of profit and share ownership schemes, could have raised productivity by 1.1 and 2.0 per cent, respectively (while the growth in selfemployment may have reduced it by 0.4 percent). Thus, the various reforms of Conservative administrations are estimated to have improved British productivity by 7 per cent, or roughly 0.35 per cent annually. This is in the order of one quarter of the observed difference in growth rates between 1960-79 and 1979-99. ${ }^{11}$

In sum, Mrs. Thatcher's reforms appear to have played an important role in Britain's aggregate economic growth. The productivity gap was eliminated and work effort rose. Despite these improvements, there has also occurred a sharp increase in earnings inequality. Because it is conventional to attribute this development in part to union decline (e.g. Schmitt, 1995; Machin, 1997), it requires close scrutiny here. 


\section{The Rougher Edges?}

The UK's earnings distribution has ADMITTEDLY widened considerably over the period since Thatcher attacked the unions. The question arises as to whether there is a connection. Schmitt (1995, p. 201), for example, noting the 'striking' inverse relation between union density and earnings dispersion, has calculated that the decline in union density could account for 21 per cent of the rise in the pay premium for a university degree, 1978-1988, and 13 per cent of the rise in the non-manual differential. Machin (1997, p. 653) has obtained an even larger figure. Comparing 1983 with 1991, he has estimated the male earnings variance would be 40 per cent less if the 1983 levels of union coverage prevailed in 1991.

On the other hand, the emphasis has been changing recently. Gosling, Machin and Meghir (2000, p. 661) do not mention unions in their analysis of the changing distribution of UK male wages. Instead, they emphasise education: the way recent cohorts have improved their acquisition of education, as well as changes over time in the returns to education. Moreover, Card (1998) has pointed out that the equalising effects of unionism can easily be exaggerated. It is necessary to allow for the fact that unionisation effects vary across the wage distribution. He shows that if the structure of unionisation changes, so that union density falls more over time for the lower paid - as has happened both in the US and the UK (see below) - then estimates of the equalising tendency of unionisation must be reduced.

Let us now detail changes in the structure of unionisation over the last twenty years. For the early period, we use the 1983 General Household Survey (GHS) dataset (see also Machin, 1997; Gosling and Lemieux, 2001). 1983 is the only year in which the GHS included a union membership question, but this year is early enough to represent the "golden age" of unionism. For the later period, we use the 1995 Labour Force Survey (LFS), 1995 representing the nadir of the union movement's fortunes. Union status is measured by a similar question in both surveys: 'Are you a member of a trade union or staff association'? ${ }^{12}$ And comparable earnings and other background information are also available. We can therefore use these two surveys to span the period in which union power changed most, and can consider the effect of union membership on wages, ceteris paribus. 
(Table 2 near here)

Table 2 gives a picture of changes in union membership over the 1983-1995 period. The sample is restricted to individuals aged 16-66 years, not self-employed, and with positive earnings. In addition, the wage data have been converted to 1995 values using the retail price index, and observations with hourly wages outside the $£ 1$ to $£ 45$ range were deleted. The table documents the well-known decline in union membership for both men and women, but shows this decline has been uneven. In 1995, aggregate membership was only 64 per cent of its 1983 level for men, and 71 per cent for women. But the pattern of membership gains and losses varies by education, age and region. Those with degrees have registered the least decline in membership, while the younger workers, and those with least education, have registered the most. The South continues to be the least unionised region, and male membership has fallen faster here than in other regions. Finally, public sector unionisation has held up well, particularly for women.

(Figures 1 and 2 near here)

A way of showing how unionisation favours the more skilled, following Card (1998), is to define predicted wage percentiles based on the non-union wage structure, and to compare union densities using these percentiles (see the Appendix). The picture is given in Figures 1 and 2, which graph union density by predicted wage percentile for males and females. ${ }^{13}$ For males in 1983 , we see that union membership is lowest among the least skilled (lowest decile), highest at the third decile, then somewhat lower for the more skilled. The 1995 data show a different pattern, with density falling most among the least skilled, leaving the highest density at the top decile. For females, density has also fallen most among low skill groups, although with some fall at the top decile as well. Thus, unionisation appears to have shifted ever more towards benefiting a labour "elite".

(Table 3 near here)

Table 3 has panels for 1983 and 1995, showing how the variance in wages has increased over the period. For men the increase has been nearly 50 per cent, from 0.223 to 0.328 , and for women somewhat less, from 0.196 to 0.26 . These increases are what we are concerned to explain. The table also shows the variance in wages for union and nonunion workers separately. It can be seen that the union wage variance is lower than the non-union - hence the equalising effect of greater unionisation. Interestingly, it can also 
be seen that while both union and non-union wage variances have risen over time, the union variance for men remains much smaller than the non-union: the union-nonunion "variance gap" remains substantial. Thus, male unions, even though less extensive than heretofore, can still strongly "standardise" their members' wages.

Table 3 also contains information on the union-non-union wage gap, both unadjusted and adjusted for a set of basic human capital variables. The unadjusted wage gaps are always larger than the adjusted gaps, because union workers have higher skills than their non-union counterparts. However, the difference between adjusted and unadjusted wage gaps grows between 1983 and 1995, reflecting the increased unionisation of high skill groups in 1995. The adjusted wage gap falls over time as well, at least for men. However, we must not be too quick to assume that this fall reflects the lower power of male unions, because we have seen that they are still powerful in reducing the union wage variance.

We can now put these facts together to estimate union effects on wage dispersion. First, we perform a simple two-sector calculation, following Freeman (1980, p. 19). Here, the effect of unions on the variance of wages (V) relative to the variance if all workers were paid according to the non-union sector wage structure $\left(\mathrm{V}^{*}\right)$ is:

$$
\mathrm{V}-\mathrm{V}^{*}=\mathrm{U} ?_{\mathrm{V}}+\mathrm{U}(1-\mathrm{U}) \mathrm{w}^{2},
$$

where $\mathrm{U}$ is union density, $?_{\mathrm{V}}$ is the union-nonunion variance gap, and ${ }_{\mathrm{w}}$ is the unionnon-union wage gap. Since unions reduce variance within the union sector, the term $\mathrm{U}$ ? $\mathrm{V}$ is the negative "within-sector" effect. The term $\mathrm{U}(1-\mathrm{U}) ? \mathrm{w}^{2}$ is the positive "between sector" effect, reflecting the fact that unions widen wage dispersion by bringing about the union wage gap.

\section{(Table 4 near here)}

Comparing the size of $\mathrm{V}-\mathrm{V}^{*}$ between 1983 and 1995 gives a measure of the effect of unions on wage dispersion. ${ }^{14}$ Such a comparison is performed in Table 4. Taking the column for men, we estimate that in 1983 unionism reduced wage variance by -0.072. In 1995 the reduction was smaller: -0.060. The implication is that if the 1983 structure of unionization prevailed in 1995, wage variance would be less by 0.012 $(=-0.060+0.072)$, or 11.4 per cent. For women the effect is larger, because unionism in 
1995 in this model actually widens the wage variance, by 0.002 . Hence if the 1983 structure of unionization prevailed, the improvement would be 0.014 , or 21.9 per cent.

(Table 5 near here)

We now allow for differences in union structure (i.e. coverage, plus wage and variance gaps) by group. The Appendix Table gives the distribution of union densities, unadjusted union wage gaps, and unadjusted union variance gaps across the wage deciles. Table 5 provides the relevant formula, and the results of the calculations. To interpret the results it is worth looking at the Appendix Table, where we see that in 1983, for both men and women, the wage gap declines nicely by wage decile, so in 1983 those with high wages receive hardly any premium, as expected. Correspondingly, the variance gap widens at higher wage decile, showing more skilled non-union workers have very varied jobs, and consequently highly variable pay. But patterns are less definite in 1995. Wage gaps are big for highly skilled workers as well - perhaps indicating that unions have gained more power at this end even while they have lost it at the lower end. The variance gap is also now large at the lower end, which chimes in with less union influence over non-union workers at this end (so their pay is more variable).

The estimates in Table 5 serve to reduce the impact of declining unionisation on wage dispersion. Looking first at men, unions reduce overall wage variance in both years: by -0.39 in 1983 and by -0.43 in 1995 . However, as can be seen, the reduction is greater in 1995, which rules out declining unionisation as a factor in the widening male wage variance. ${ }^{15}$ The main factor behind the greater dispersion-reducing effect of unions in 1995 is the wider variance gaps in 1995. In other words, unions compress pay more in 1995 than 1983. On the other hand, for women, the adjusted and simple estimates are less dissimilar. The dispersion-reducing effect of unions is now estimated to be larger in 1983 (at -0.013) than in 1995 (-0.001). Consequently, we can still allow the decline of women's union density to play some role in the widening of women's wage variance.

These results considering changes in the structure of UK unionism differ from the received wisdom, and would be worth exploring further with other datasets, and over a longer time period. ${ }^{16}$ Nevertheless, we should be alert to the possibility that UK unionisation, while it has lost members among the less skilled, has to some extent made 
up for this by gaining members among the skilled. Consequently, the equalizing effects of unions are less than might be thought.

\section{New Labour}

Prior to its election victory in May 1997, New Labour had signaled its intention to make a number of changes that would affect industrial relations practice and labor law. For example, Mr Blair had promised to recognise unions at the Government Communications Headquarters (GCHQ). ${ }^{17} \mathrm{He}$ had also announced his intention to set up a Low Pay Commission, which would resurrect minimum wages but at the national rather than industry level. Moreover, the new administration would adopt a very different attitude to Europe: in June 1997 the new government committed itself to accepting the social chapter, thereby ending a period of bifurcation in Community social policy.

In this section, we review the main changes - actual and planned - of New Labour, beginning with the new National Minimum Wage, through the 1999 Employment Relations Act, to the prospective Employment Act. The altogether more dramatic changes foreshadowed by the end of twotrack social Europe are remitted to section IV.

\section{The National Minimum Wage}

In April 1999 a national minimum wage was introduced following the Low Pay Commission's recommendation. This is the first time that the UK has had a national minimum. Trade unions have been strong supporters of the concept, aiming to take the minimum wage as a starting point for negotiations for low paid workers in the usual way (Labour Research Department, 1999, p. 10). Previously there had been an industry-based system of Wages Councils for low wage industries, set up by the Trade Boards Act of 1909. It had been hoped that these Councils would foster the growth of voluntary collective bargaining in their industries. However, trade unions were never certain whether Wages Councils were helping or hindering such growth (Donovan Commission, 1968, para. 229). Thus, given that the Wages Council system had been abolished in 1993, the move by New Labour and the unions for an alternative system of minimum wagesetting, but on a national basis, seemed natural. The question was seemingly only a matter of how high the bar should be set. 
The minimum was initially fixed at $£ 3.60$ an hour for those aged 22 years and above (see Table 6), with a youth sub-minimum of $£ 3.00$ for those aged 18-21 years (17 year-olds and under were not covered), and a development rate of $£ 3.20$ for adults in the first six months of a new job with accredited training. The Low Pay Commission (2001, Appendix 1, para.17) estimated that about 1.5 million workers (6.4 per cent of the workforce) had a pay increase as a consequence. The pay increase was large: those earning less than the minimum in 1998 had an increase of 15.5 per cent, 1998-99, as compared with only 4.6 per cent for everyone else (Low Pay Commission, 2001, para. 3.30). ${ }^{18}$ Some sectors were more heavily affected than others. Thus, Machin et al. (2002, Table 2) report in their study of residential care homes that nearly a third of these workers required a pay increase as a result of the minimum.

(Table 6 near here)

The course of the minimum, together with estimates of numbers affected, is shown in Table 6. As can be seen, there have been up-ratings annually. The table presents estimates of the numbers of workers affected by these October up-ratings calculated on the basis of wage distributions for the previous April (ONS, 2002). In other words, by taking the wage distribution six months prior to a new minimum, we estimate how many workers would have higher pay as a result of the minimum. On this basis, the October 2000 uprating meant that only 977,000 workers had a pay rise (about 4 per cent of the workforce). However, the October 2001 uprating had almost double the impact, with 1.7 million workers (7 per cent the workforce) having a pay rise. Unions have been complaining about the low coverage of the minimum, and have called for improved uprating together with abolition of the youth rate (Labour Research Department, 2001, p.12). But Table 6 makes it clear that coverage remains significant. It is also important to realise that, although only some 5 per cent of the youth (18-21 years) workforce is covered by the youth minimum, almost 30 per cent of this group would require a pay increase if the adult minimum were required. ${ }^{19}$

As regards impact on employment, the evidence is mixed. The most comprehensive study is by Stewart (2001, p. 29), who finds that introduction of the minimum had zero impact. He compared employment probabilities pre- and post-1999 for those at the minimum, and for those just above the minimum. If the minimum had had 
any effect, the employment probabilities post-1999 should have been worse for the minimum wage group. But there was no significant difference. (That said, note that this study only looks at employment development a few months after the minimum was introduced, not longer-run effects.) On the other hand, there is strong evidence of displacement effects in particular markets. For example, the Low Pay Commission's 2000 survey of low-paying firms - including hairdressing, cleaning, care homes - found that 40 per cent of the sample registered a 'significant' or 'slight' reduction in staffing levels (Low Pay Commission, 2001, Appendix Table A2.11). Furthermore, the study of residential care homes by Machin et al. (2002, p. 19) detects reductions in both employment and hours following the minimum, with an employment elasticity in the region of -0.15 to -0.40 . Particularly striking is the fact that the rate of employment growth of care assistants has fallen to zero since 1999, having increased steadily in the previous five years. Clearly minimum wages can bite.

\section{The 1999 Employment Relations Act}

The shape of the government's industrial relations policies became clear with the publication of the White Paper Fairness at Work (Department of Trade and Industry, 1998). This emphasised both the domestic and the European dimensions. On the purely domestic front, its main but not exclusive thrust was the establishment of new procedures for collective representation. On the European front, national law would have to reflect decisions taken in the European Union (EU) under the Agreement on Social Policy - now the social chapter (see section IV). Yet, as indicated by his 'there will be no going back' statement cited at the start of this essay, Mr. Blair was careful to retain the curbs on industrial action and the impediments the closed shop that he had inherited.

New Labour's amended proposals became law in June 1999. Only the barest bones of the legislation are summarized in the final row entry of Table 1; even so, the contrast between the 1999 Employment Relations Act and preceding legislation is sharp. We now add some flesh to these bones, as well as commenting briefly on the 'family friendly' provisions of the Act.

Beginning with the union content, the main element in the legislation is the establishment of a statutory union recognition procedure for all firms employing more than 20 workers in the event that a union claim for recognition (identifying the union and 
the bargaining unit involved) is rejected, unanswered, or otherwise not negotiated by the employer. In these circumstances, the union can apply to the Central Arbitration Committee (CAC) for recognition, thereby activating a statutory recognition procedure. The CAC has to decide whether the proposed (or indeed some other) bargaining unit is appropriate and whether or not the union has the support of a majority of members of the appropriate bargaining unit. Once the definition of the bargaining unit is decided (and here prime consideration is supposed to be given to its compatibility with 'effective management'), the CAC determines whether the union is able to demonstrate that the majority of unit is in favour of membership. Union recognition will be awarded automatically if the CAC is satisfied that majority of members of the bargaining unit are union members. If not, the CAC has to arrange for a secret ballot. Recognition is granted if a majority of those voting are in favour, providing that they constitute at least 40 per cent of the bargaining unit.

A method of collective bargaining can be imposed by the CAC at the request of either party in circumstances where its award of recognition has not resulted in collective bargaining either because of failure to agree on a method or failure to follow an agreed method, or in the case of voluntary recognition agreements for the same reasons. Here the Act provides for the establishment of a joint negotiating body and a six-step bargaining procedure to cover the determination of pay, hours, and holidays (on an annual basis).

A second major advance for unions ushered in by the legislation is the right for all workers (not just union members) to be accompanied by a trade union representative in grievance and disciplinary hearings. Data from the 1998 Workplace Employee Relations Survey show that, although most firms currently allow employees to be accompanied by a third party, less than one half allow them to choose whoever they wish (Cully et al., 1999, p. 97). As a result, non-union firms are now likely to be faced 'not with a workplace representative, but with a full-time union official who will probably be seeking to maximise recruitment' (IRS, 1999, p. 10). Note that this right to representation is independent of the recognition procedure and applies irrespective of the size of the firm.

Third, although the Act does not alter the basic legal principle that strikes have to be supported by valid ballots, it does relax strike balloting procedures. Thus, for example, 
unions will no longer be required to furnish employers with the names of members that are being balloted or called out on strike - although the 1993 requirement of seven days advance notice of a ballot is still required of the union. ${ }^{20}$

Fourth, strikers are specially protected against dismissal. Prior to the Act, even strikers on official strike could be dismissed fairly unless they were able to show that the dismissal was selective and motivated by an anti-union animus. Henceforth, dismissal of those on lawfully organised industrial action will only be fair if the employer can demonstrate that 'reasonable' procedural steps to resolve the dispute have been undertaken - and even then only eight weeks after the striker has been on strike. Employees who believe they have been dismissed unfairly in this regard can petition an employment tribunal. Further, the Act raises the maximum penalty for unfair dismissal from $£ 12,000$ to $£ 50,000$ (in fact, with special awards, the maximum is closer to $£ 68,000$; see IRS, 1999, p. 8). The qualifying service period is also abolished for strikers. (For the workforce as a whole, the qualifying period is reduced from two years to one year.) The clear intention is to ensure little threat of court actions against striking workers in the future. $^{21}$

As was noted earlier, the Act also contains family friendly measures, defined as policies that enhance family life while making it easier for people to go to work with less conflict between their responsibilities at home and at work (Department of Trade and Industry, 1998, p. 9). In normal circumstances, statutory provision of improved labour standards might be expected to diminish the demand for unionisation on the part of workers or reflect decreased unionisation. But note that family friendly measures are essentially part of the corpus of European social policy, which as we shall see contains many directives of direct benefit to union organisation. The two main provisions in question pertain to maternity/parental leave and part-time work, transposing into UK law the provisions of two EU directives. In the former area, the Act increases the period of basic maternity leave from 14 to 18 weeks. It also provides the right to additional leave for women with one year of service with their employer (rather than two years as heretofore). Three months parental leave is also extended to mothers and fathers (and adoptive parents) of children under five, born after 15 December 1999. For their part, the atypical work provisions seek to ensure that part-time workers are treated 'no less 
favourably' than their full-time counterparts as regards their terms and conditions of employment. These two transpositions phased in under the ERA follow on the heels of the domestic application of much more controversial European legislation in the form of the working time and European Works Council directives considered in section IV below.

\section{The Employment Bill}

New Labour's Employment Bill was first submitted to Parliament in November 2001 and at the time of writing has yet to become law. Outside of disputes resolution it has little obvious relevance to unions. ${ }^{22}$ That the emphasis of the draft legislation lies elsewhere namely, maternity leave and fixed-term contracts - was nevertheless widely interpreted at the time as indicating that there was no unfinished "union business".

The Bill contains maternity leave provisions that extend the amount and duration of paid leave for mothers. ${ }^{23}$ These terms are accompanied by paternity leave for fathers (two weeks' paid leave on top of the 13 weeks' unpaid leave under the existing law), again subject to a minimal service (and threshold earnings) requirement, as well as paid adoptive leave of 26 weeks' duration. Each measure is part of New Labour's family friendly legislation mentioned earlier. Also included under this heading are the proposals pertaining to fixed-term contracts, to be the subject of formal Regulations. These will transpose into UK legislation the provisions of supranational EU legislation (see below) providing no less favourable treatment for workers on fixed-term contracts than for regular employment. Apart from the discrimination component, the Regulations will also set the terms under which such contracts can be extended and the circumstances in which they will instead be deemed converted into open-ended employment. The regulation of atypical work may of course facilitate union membership directly by "regularising" it or indirectly by increasing the cost of a substitute for union labour.

Finally, the most important component of the provisions on dispute resolution is the insertion of a statutory three-step disciplinary and grievance procedure into the written contract of employment. The aim here is to reduce the attractiveness of employment tribunals, recourse to which has been running at record levels. Thus, in 1990/1, there had been only about 40,000 employment tribunal applications, but by $2000 / 01$ this had risen to nearly 140,000 - with an embarrassingly fast increase since 
1997 (Department of Trade and Industry, 2001a, p. 28). The government thought it could reduce this figure by requiring firms to adopt model "disciplinary" and "grievance" procedures, to include details of these procedures in the employee's written statement of employment, and to allow tribunals to take into account, when ruling on compensation, whether this procedure had been properly used (Department of Trade and Industry, $2001 b$, p. 18). However, as a practical matter, the increase in tribunal applications is mostly fueled by extra employment rights (and extra entitlement to compensation) rather than to "bad management". Accordingly, we doubt whether the measures will succeed in damping down the future course of tribunal applications.

\section{The Economic Consequences of Mr. Blair}

Early assessments of the effects of policy shifts are fraught with difficulty (see for example, Coutts et al. 1981). Unbowed, in an early assessment of the proposals in Fairness at Work, Minford and Haldenby (1999) argued that the new recognition procedures could result in one million new union members. This calculation is based on a Confederation of British Industry survey of expected claims for recognition. Minford and Haldenby then use the Liverpool macro-model to estimate the costs of the new recognition procedures - and indeed all the regulatory aspects of Fairness at Work. Via the projected increase in wage demands in line with increased membership, the disemployment costs of the new recognition procedures are set at half a million workers after two years, which certainly seems too high.

The government's statutory recognition procedures came into force in June 2000 and the signs do point to an increase in recognition. Thus, the number of recognition agreements recorded by the TUC which had doubled in 1999 over 1998, more than doubled again in 2000 to 159 agreements covering 58,233 workers (see TUC 2000, 2001; see also EIRR, 2001). Note also that union membership rose modestly in 2000 for the first time in 20 years.

But New Labour has not sought systemic reform of the Thatcher law legacy. Thus, legislation on the closed shop, the various constraints on industrial action, elections for union officials, and membership rights against the leadership has not been subject to change. Nor for that matter has there been any attempt to alter the financial reporting obligations of unions, or to reinstate the Fair Wages Resolution or the statutory extension 
of collective bargaining. The new administration can also be said to have been responsive to the needs of industry in seeking to limit the domestic impact of a number of pieces of EU legislation, most notably the Working Time Directive, and in resisting one-size-fitsall draft legislation on European consultative rights (Brown, 2000, p. 304). What we instead have is a so-called third way, the elements of which comprise an extension of individual employment rights, a modicum of protection for low paid workers under the NMW, family friendly or work/life balance policies, and the goal of social partnership or cooperative unionism (facilitated in part through help on recognition). ${ }^{24}$

New Labour's policies have tended to draw more criticism from its friends than its opponents. Thus, its entire programme has been termed minimalist, by virtue of the absence of any unfinished business (i.e. new union legislation) in the current Employment Bill as well as the government's attempts to date to limit the impact of EU directives referred to earlier (Smith and Moreton, 2001). For its part, the government would emphasise the importance of its notion of "partnership" at the workplace or mutual cooperation. $^{25}$ Partnership is certainly the leitmotif of Fairness at Work. Witness the statement: 'Within Britain's flexible and efficient labour market, the Government is proposing in this White Paper a framework in which the development of strong partnerships at work can flourish as the best way of improving fairness at work' (Department of Trade and Industry, 1998, p. 8). The other hallmark of the White Paper, at least as conventionally depicted, is the focus on individualism (Brown et al., 2000).

But this is patently not the end of the story. The second quotation of Mr. Blair at the start of this essay necessarily marks a shift away from individualism. The issue here is one of whether unions facilitate effective partnership. The scene is set for a replay of the old controversy about unions and efficiency in an environment of more cooperation between the two sides of industry which is, to complicate matters analytically, in part a symptom of a weakened union movement' (Brown, 2000, p. 308). Interestingly, some of the first salvoes in this controversy are fired in this Handbook (see Chapter 5). The second reason is the EU context. Almost irrespective of Mr. Blair's acceptance of the EU model, it is the case that domestic law on industrial relations will increasingly be driven by the acquis communautaire, to which we now turn. 


\section{The European Level}

Within a month of its election victory New Labour opted in to the Agreement on Social Policy (ASP). The ASP was the device used to save the 1991 Maastricht Treaty in the face of continuing British opposition to pan-European labour standards. The formula chosen was to relegate the terms of what was to have been a social chapter to a protocol appended to the treaty. Attached to the protocol was an agreement - the ASP - that noted the intention of the other (at that time) eleven member states to pursue a new route to social policy with the specific exemption of the UK. This process heralded the emergence of what has been called a 'two-track' social Europe; the other track being the standard and narrower treaty route. Labour's return to the fold merged the two tracks. This merger was formalised with the conclusion of the Treaty of Amsterdam in October 1997, which incorporated the provisions of the ASP directly into the main body of the treaty - a social chapter after all. What has the UK let itself in for; and, in particular, what are the implications for collective bargaining?

\section{The Agreement on Social Policy}

The ASP made two fundamental changes. First of all, it provided for the first time a firm treaty basis for social policy legislation in identifying ten distinct social policy themes, in five of which qualified majority voting (rather than unanimity) would apply. ${ }^{26}$ Second, it gave the two sides of industry at European level - the 'social partners' - an elevated role in determining policy. ${ }^{27}$ The aim is to have the two sides consulted by the Commission on the possible direction of social policy, and also to "take over" any legislation and reach a framework agreement between themselves on measures that would duly become binding across the EU. This move towards corporatism might result in better (i.e. employment increasing) policy making ${ }^{28}$, but it does of course also serve to legitimise the activism of the social affairs directorate.

Since ratification of the Maastricht Treaty in 1993, the social partners have had mixed success. They were able to reach agreements on parental leave, part-time work, and (most recently) fixed-term contracts - agreements that were subsequently given the force of law by Council directives. But in all cases where they were unable to reach agreement, the Commission advanced its own proposals. And it was able to secure legislation on European Works Councils (EWCs), the burden of proof in gender 
discrimination cases, and, most recently the directive on national works councils. The Commission was also to use the standard treaty route, that is, process legislation before all 12 (now 15) member states. ${ }^{29}$ In short, both the ASP and the standard treaty routes were used to attend to unfinished (social charter) business and to advance new proposals.

The immediate effect of New Labour's opt in was that there was a body of European legislation on the books that the UK had had no say in framing and now had to implement. $^{30}$ Although formal application of the Treaty of Amsterdam would be delayed until each and every member state had ratified it (May 1999), it proved possible to extend the law to the UK well before then by readopting ASP legislation on a whole-Community basis. Much more important than catch-up, however, was the progression of draft legislation and new initiatives with the UK rejoining the fold the end of two-track social Europe. Recall that Community social policy now enjoys not only an unambiguous treaty basis but also equal billing with economic integration in the European endeavour.

\section{The Skein of EU Union-Related Law}

\section{Health and Safety Consultation}

British legislation predating Community social policy required the employer only to consult recognized unions via health and safety committees. However, Council Directive 89/391/EEC of 12.6.89 established general principles for information, dialogue, 'balanced participation', and training for workers and their representatives. Non-union employees had to be consulted as well. Thus, current British practice, under The Health and Safety (Consultation with Employees) Regulations (SI 1996/1513), requires that employees not in groups covered by union health and safety representatives now have $\mathfrak{b}$ be consulted - either directly or through elected employee representatives - by their employer. Consultation rights are extensive and range from changes in, say, ways of working that affect employees' health through information on likely risks and remedial action, to training. The implication is that the UK model, which has traditionally required collective bargaining is inadequate, with the decline in unionism. The Commission perceives a need for wider employee representation, the stimulation of which could well promote unionism as we shall see.

\section{Collective Redundancies and Transfers of Undertakings}

Community legislation on worker rights in the event of collective redundancies (i.e. mass 
layoffs) and transfers of businesses was contained in the Commission's first social action plan, and dates from 1975 and 1977, respectively. As in the case of health and safety, both laws call for employee representatives and the provisions are the same in each case.

The current EU law on collective redundancies is Directive 98/59/EC of 20.7.98. A collective redundancy is defined as a permanent layoff involving 20 or more employees at a single establishment in a 90-day period. Consultation has to cover ways of avoiding the dismissals and mitigating the layoffs and their consequences. It has furthermore to be conducted with a view to reaching agreement and must provide written details on the redundancies to employee representatives. ${ }^{31}$ The timing of consultation is a function of the number of layoffs: at least 90 (30) days prior to the first dismissal if 100 or more (between 20 and 99) redundancies are proposed. Penalties for failure to consult are up to 90-days' pay for each affected employee under a protective award issued by an industrial tribunal.

Again until quite recently, UK law made no provision for affected employees not represented by a union. But under the Collective Redundancies and Transfer of Undertakings (Protection of Employment) (Amendment) Regulations 1999 (SI 1999/1925), the employer has now to inform and consult appropriate representatives of these employees, who may be existing representatives - if their remit and method of election or appointment gives them suitable authority from the employees concerned - or newly elected representatives. (If employees fail to elect representatives within a reasonable time then employer has to consult directly with the affected employees.) The new legislation sets down a 9-item set of rules to apply in cases where employee representatives are to be specially elected. For example, the employer has to determine the number of representatives to be elected so that they are sufficient to represent the interests of all the affected employees having regard to the number and classes of those employees, and before an election the employer has to determine the length of office of the representatives which has to be long enough to meet the information and consultation requirements. These requirements can stimulate unionism for two reasons: first, the circumstances of redundancy concentrate the minds of employees and can well tip the scales in favour of union organisation; second, the unions should be able to work the complex new rules best. 
EU regulations pertaining to transfers of businesses - or 'acquired rights' - have recently been revised as a result of Directive 2001/23/EC of 12.3.01. The British enabling legislation is The Transfer of Undertakings (Protection of Employment) Regulations 1981 (SI 1981/1794), as amended in amended in 1995 (SI 2587) and 1999 (SI 1925). Abstracting from the changing technicalities of what precisely constitutes a business transfer, the regulations have the effect: first, that employees of the undertaking which changes hands automatically become employees of the new employer on the same terms and conditions; and, second, that representatives of affected employees have a right to be informed about the transfer and to be consulted (with a view to securing their agreement) about any measure contemplated by the old or new employer that will affect these employees.

The provisions on representatives are identical to those described for collective redundancies. Breach of the regulations can result in up to 13 weeks pay per affected employee. Where the cause of action involves collective redundancies as well $\mathrm{s}$ acquired rights, the penalties are in principle additive rather than offsetting.

\section{The EWC Directive}

Community draft legislation on transnational works councils dates from 1975, although the present directive stems from the action programme of the social charter. Passage of the legislation was delayed by British opposition, so that the European Works Council Directive (94/45/EC of 22.9.94) was adopted under the ASP. It requires consultative workers' councils in companies with at least 1,000 employees in the Community and with at least 150 employees in each of two member states, if requested by employees. Member state implementing provisions had to be in place by September 1996, establishing a formal procedure for the negotiation of an EWC (under Article 6 of the directive). Failure to reach agreement under this procedure within three years would trigger a statutory works council (i.e. after September 1999). By the same token, Article 13 of the directive also recognized voluntary works council arrangements - "Article 13 agreements" - where these could be concluded prior to the passage of national legislation. Note that the legislation allowed for its review: 'Not later than 22 September 1999, the Commission shall in consultation with member states and with management and labour at European level, review its operation and, in particular, examine whether the 
workforce thresholds are appropriate with a view to proposing suitable amendments to the Council, where necessary'.

As we have noted, ASP legislation does not apply to the UK. After the British opt in, therefore, it became necessary to extend the law to the UK. This was done in December 1997 via Directive 97/74/EC. The British enabling legislation - The Transnational Information and Consultation of Employees Regulations 1999 (SI 199/3323) - gave UK-based multinationals until 15 December 1999 to negotiate Article 13 agreements and a further three years to avoid statutory EWCs.

In what sense does this legislation strengthen unions? After all, it gives no role to unions per se; rather, negotiations are via a special negotiating body, the (UK) members of which are elected by secret ballot of the workforce, with no provision for nomination by existing employee representatives. Nevertheless, we know that unions have played a key role in negotiating EWCs (e.g. EIRR, 2000a, p. 22). That said, we also know that the experience with EWCs - admittedly most of which have been Article 13 agreements (i.e. voluntary arrangements) - has been benign and the immediate cost implications seem modest (see, respectively, Addison and Belfield, 2002c; Department of Trade and Industry, 1999). ${ }^{32}$ So the issue hinges on the directive's relationship to the information and consultation requirements of the other mandates reviewed here and, relatedly, on the next revision of the law when the Commission is likely to lower the employment size threshold, strengthen the information and consultation rights, and elaborate on the procedures (more meetings, training of EWC members, and enhanced rights to expert assistance). These at least are the recommendations of the ETUC (EIRR, 2000b, p. 21). Finally, there is the vexed issue of the EWC as a springboard for pan-European collective bargaining (see Chapter 14 of this volume).

\section{The European Company Statute}

A thirty-year deadlock on provision for a European Company Statute (ECS) was broken in October 2001 with the adoption in Council of legislation establishing the legal basis of the European Company (Regulation (EC) No. 21257/2001 of 8.10.01) and its twin covering employee involvement in the new entity (Directive 2001/86/EC of 8.10.01). The legislation will come into force in October 2004. The European Company is a form of legal entity available on a voluntary basis to companies operating in more than one 
member state and wishing to take advantage of a unified tax structure. The arrangements for employee involvement in the ECS resemble those for EWCs but there are some important differences that will presumably require early modification of the directive governing the latter. Put simply, the legislation provides for free negotiations between management and employee representatives with the goal of reaching a voluntary agreement on employee involvement arrangements. But management has to initiate the special negotiating body (SNB) procedure, which also differs in a number of respects from the EWC counterpart. In particular, in determining the rules for the election of SNB members, member states can make provision for trade union representatives who need not be employees of the company. Further, union representatives are explicitly mentioned among the 'experts' that the SNB can request to assist it.

The negotiating process must begin as soon as the SNB is established, and just six months are allowed for negotiations - as compared with three years in the EWC case although this interval may be extended at the joint request of the two sides. Voluntary agreements have to meet a number of basic conditions as with the EWC (e.g. composition of the 'representative body', frequency of meetings, and financial resources allocated to it) but in addition to information and consultation there is also the possibility of boardlevel representation. The inclusion of such representation is largely optional but if a single company converts to a European company preexisting levels of board representation continue to operate.

Failure to reach an agreement again generates a set of standard rules on employee involvement. These not only provide for information and consultation through a 'representative body' - that on occasion exceed the standard set for the statutory EWC but also for board level representation in certain cases.

\section{National Systems for Consulting and Informing Workers - or Company Works Councils}

The ECS just described is voluntary, while EWCs pertain to multinationals alone. However, the Community has just passed similar information and consultation requirements that will cover the generality of employers. Directive 2002/14/EC establishing a general framework for informing and consulting employees in the European Community came into force on 23 March, 2002. The directive was initially proposed by the Commission in 1997 but as with the ECS its origins go back much 
further, and can be traced back to the 1972 Fifth Company Law draft directive and its subsequent iterations (Addison, 2000; Addison and Siebert, 1991, 1994).

The directive is to be implemented within three years. At the discretion of the member state, it applies either (a) to undertakings with at least 50 employees in any one member state, or (b) to establishments employing at least 20 employees in any one member state. The UK has chosen the former option, and has also negotiated transitional provisions. Specifically, the UK is permitted in the first instance to restrict the application of the directive until March 2007 to businesses with 150 or more employee and then, for a further year, to businesses with at least 100 employees.

The directive leaves the precise form of mechanism to the member state but requires that employers inform employees about the undertaking's economic situation, and consult them on employment prospects (including threats to employment and anticipatory measures to deal with them) as well as on decisions likely to lead to substantial changes in work organization or contractual relations. Information and consultation provision has to be with 'employee representatives', but these can be defined according to national law and practice. Employers and employees can negotiate procedures for informing and consulting employees that differ from those set out in the directive so long as existing agreements on information and consultation meet their obligations. Finally, the Commission will oversee operation of the directive by March 2007 again with a view to proposing any 'necessary amendments'.

Trade unions have generally been supportive of the directive, although the UK government has been more cautious. For the unions, the directive opens up the possibility of easier organising, using the works council as a vehicle. ${ }^{33}$ More directly, the directive will raise UK employment standards. In the words of one prominent union generalsecretary, it will no longer be 'cheaper and easier to sack workers in the UK' (Lyons, 2002, p. 15). ${ }^{34}$ In fact, the switch to a broad, permanent and statutory system of workplace representation in the UK should have far-reaching consequences for the pattern of trade unionism. Unions may well become more powerful in wage- and standard-setting centrally along corporatist lines, even if developments at workplace level are less obvious. (Thus, a short-term fillip to membership from employee involvement legislation might not be sustainable longer term.) 


\section{The EU Charter of Fundamental Rights}

We conclude this review of specific instruments with brief commentary on the littleknown EU Charter of Fundamental Rights of September 2000 (for an accessible review of which, see EIRR, 2000c). From our perspective the key features of the Charter are the solidarity clauses of Articles 27 and 28. The former states that 'workers or their representatives must, at the appropriate levels, be guaranteed information and consultation in good time and under the conditions provided for by Community law and national laws and practices'. The latter provides that 'workers and employers, or their respective organisations, have, in accordance with Community law and national laws and practices, the right to negotiate and conclude collective agreements at the appropriate levels and, in cases of conflict, to take collective action to defend their interests, including strike action'.

In both cases, interest has centred on the substitution of the term 'at the appropriate levels' for the 'at all levels' contained in the interim draft. The changes in question since they do not guarantee more than what already exists under national law together with the status of the Charter as a non-binding declaration rather than an element of the new Treaty of Nice - are widely viewed as a defeat for unions e.g. Hendy, 2001). The role of the UK government in spearheading opposition to the Charter is notable - on the grounds that its package of economic and social rights conflicted with the needs of the largely deregulated British labour market. But the Charter is best viewed as a starting rather than end point. As the experience with the 1989 social charter demonstrates, nonbinding instruments can be used to justify all manner of subsequent interventions.

\section{A Summing Up}

The fact that the UK is now fully obliged to transpose EU directives into national law means that the influence of Europe will increase, even if New Labour will likely seek to weaken their impact. As in the past, the main effect will be on legal regulation of the employment contract rather than on unionism per se (see Addison, 2001; Addison and Siebert, 1991, 1994). Although the emphasis on labour conditions and standards will not diminish, the international dimension seems set to increase in importance and this carries domestic implications for freedom of association and recognition of the right to collective bargaining (see Commission, 2001a). In addition, the Commission will focus on the 
consequences of industrial restructuring, one important aspect of which will cover the social responsibilities of companies (Commission, 2001b). Employee involvement measures complementing those described above are, then, in the offing and these may be expected to further strengthen union influence, if not necessarily at the workplace.

The EU social policy agenda (Commission, 2000) is an active one, and to faciliate its passage the Commission places particular emphasis on the value of social partner negotiations in 'modernising and improving employment relations' inter al. To be sure, the partners sometimes refuse to play ball - as in the case of the latest directive on national systems for informing and consulting workers - but the process of social dialogue is ever widening in scope. While the emergence of European collective bargaining may be a long way off (for reasons discussed in Chapter 14), the sustainability of the independence of British collective bargaining procedures seems under greater pressure than ever.

\section{Conclusions}

The present chapter has indicated that laws do matter. The aggressive reforms of Mrs. Thatcher seem to have reduced union bargaining power, membership, and coverage. But the laws were part of a wider deregulatory agenda that sought tax reduction, denationalization, pension privatisation, changes in macroeconomic management, the excision of wage floors and other props to collective bargaining, the abandonment of exchange controls, and a modicum of welfare reform. So contextualised, the union reforms seem to have worked. As cases in point we identified unambiguous improvements in the productivity levels, productivity growth rates, and profitability of union establishments vis-à-vis their non-union counterparts as well as a marked improvement in the nation's aggregate economic growth relative to Germany and France. Not surprisingly, the gains were not recorded overnight. And to be sure there was a downside in the form of widened earnings inequality; the other side of the coin being a faster growth in income. Interestingly, our analysis revealed that the facts of union decline contribute rather little to this development.

That was then and New Labour is now. A case can be made that Mr. Blair's domestic agenda has not badly rocked the Thatcher boat, despite some scary initial 
estimates of the cost of Fairness at Work. Indeed, even if Mr. Blair had sought to restore union immunities and set the legislative clock back to 1975, the scope for British unions to influence/dictate events is palpably smaller today than heretofore. As Machin (2000, p. 643) has argued: "the increasingly powerful "new economy" seems to offer little role or place for trade unions'. But that which may defeat a purely domestic challenge to the Thatcher inheritance applies with much reduced force to entities that are less engaged in 'foreign' trade such as the EU where there is scope for pan-European (even global) rule making. Indeed, we have conjectured that Mr. Blair's acceptance of the social chapter will do more to revive British unionism than any item of his domestic agenda. We also incline to the view that he did not fully anticipate the consequences. And there is a precedent here: some two decades earlier Margaret Thatcher accepted an extension of qualified majority voting in the Council of Ministers in return for speedier achievement of economic union without fully understanding the consequences for social union. Be that as it may, the next issue is whether British unionism is a changed animal, so that the consequences of high density today are anyway very different from yesteryear. Some observers are of the opinion that there has been a sea change and thus see much to commend the greater degree of employee involvement deriving not only from the EU legislation that we have documented but also from New Labour's avowed partnership approach (see Department of Trade and Industry, 2002; and Chapter 5 of this volume). Since research has thus far inadequately informed us as to the efficacy of high performance workplaces and ambitious systems of worker involvement (organic or otherwise), we can at least conclude that these are in fact exciting times for the economic analysis of unions in general and British unions in particular. 


\section{Endnotes}

${ }^{1}$ This subsection and Table 1 draw on Addison and Siebert (1998, 2001).

${ }^{2}$ Until 1971 unions were protected from common law actions based on restraint of trade through statutory immunities granted under the 1906 Trade Disputes Act (on the immunities system, see Deakin and Morris, 1995, pp. 758ff.) Thus, unions were exempted from all liability in tort and union organisers were protected from certain such liabilities when acting in contemplation or furtherance of a trade dispute. Striking workers for their part enjoyed no such immunity. In 1971, under the Industrial Relations Act, a Conservative administration offered unions legal rights - including union recognition - rather than immunities in exchange for stricter control of strikes. The legislation attempted to impose a US-style industrial relations framework, with a labour court, a mechanism for recognizing unions which could then form 'agency shops' similar to those permitted by the Taft-Hartley Act of 1947, a set of 'unfair labor practices', including unfair dismissal (for the first time in British law), and legally enforceable collective agreements. The measure was unsuccessful, largely because the Trades Union Congress (TUC) discouraged unions from registering under the Act - although the concept of 'unfair dismissal' remained and has indeed been tightened over the years.

3 Nearly 400 claims a year were being made by unions under the legislation in the late 1970s (ACAS, 1981, Table 10).

4 A further piece of legislation, the 1989 Employment Act, lifted restrictions on the working time women and young workers, exempted small firms from some employment law, and limited the right to time off with pay for trade union duties.

5 The Fair Wages Resolution dated from 1909. It required all government contractors to pay rates of wages and observe hours of work that were not less favourable than those 'commonly recognised by employers' or those 'which in practice prevail' - which in practice came to mean union rates.

6 Some stiff financial penalties were imposed. Examples include a $£ 650,000$ fine on the National Graphical Association in 1984 and the sequestration of $£ 707,000$ of the assets of the National Union of Mineworkers (Marsden, 1985, p. 157).

7 Manning argues that the requirement for pre-strike ballots - introduced under the 1984 Trade Union Act (see Table 1) - has led to a decline in union influence over employment. In multiplant undertakings, unions could in earlier times keep open unprofitable plants by threatening to strike profitable ones. Requiring unions to ballot members destroys the credibility of this threat because workers whose jobs are not in jeopardy are unlikely to vote for a strike.

${ }^{8}$ It will be recalled that collective voice can provide a mechanism for overcoming many of the public goods aspects of the workplace. By aggregating worker preferences, unions can thereby enable firms to choose a more efficient mix of wage and personnel policies. Union voice may also open creative channels of communication with management, and 
enhance management decision-making. Further, unions that have a say in how worker information is used by management may stimulate the disclosure of pro-productive private information by workers

9 Interestingly, Bryson also suggests that strong (weak) unions may be an efficient (inefficient) agent for management as well. Here he is apparently exploiting another public goods dimension of the workplace that arises when there are important complementarities in the production process, even if joint determination of effort does not necessarily imply that the union will be the employer's monitor of the employees.

${ }^{10}$ Pencavel (2001) chooses to stress the abandonment of full employment policies.

11 Some corroboration of these results is offered in regressions of levels of and changes in output and employment on (one of) the reputation indices over the interval 1970-95.

12 There is also a union coverage question in both surveys, but the questions are somewhat different. In the GHS the question is: 'Is there a trade union or staff association where you work, which people in your type of job can join if they want to?' In the LFS the question is simply: 'At your place of work, are there unions, staff associations, or groups of unions?'

13 The prediction equation is based on Card's specification (1998, p. 10), and includes education years, dummies for colour, marital status and (4) regions, linear, quadratic and cubed experience, and interactions of five levels of education with linear and quadratic experience. It is fitted to non-union workers only, and then used to assign union and nonunion workers into ten equally-sized groups.

${ }^{14}$ We follow Card (1998) here. Alternative measures are possible; for example, Gosling and Lemieux (2001, p. 18) compare 1998 with 1983 by computing ? ${ }_{0}=\mathrm{V}-\mathrm{V}^{*}$ for 1998 given the 1983 level of unionisation. Then (with 1, 0 representing the two years), the change between the two years is: ? ${ }_{1}-?^{\prime}{ }_{0}=\mathrm{U}_{0}\left[?_{\mathrm{V} 1}-? \mathrm{v}_{0}\right)+\mathrm{U}_{0}\left(1-\mathrm{U}_{0}\right)\left(? \mathrm{w}^{2}{ }^{2}-? \mathrm{w}_{0}{ }^{2}\right)$. This measure holds constant changes in union variance and wage gaps over the period which seems arbitrary (see also Machin (1997, p. 652) for a use of this method).

${ }^{15}$ We can also calculate some Gosling and Lemieux measures:

$1995 \mathrm{~V}-\mathrm{V}^{*}$ : actual with $1983 \mathrm{U}$ with $1983 ? \mathrm{w} \quad$ with $1983 ? \mathrm{~V}$

$\begin{array}{llll}-.043 & -.074 & -.042 & -.027\end{array}$

Thus, the 1995 variance would be -.031 (=-.074+.043) smaller if 1983 union densities prevailed. But there would be other effects given the 1983 variance and/or wage gaps, so it seems better to consider all three effects together.

${ }^{16}$ But see Gosling and Lemieux (2001) on the difficulties of time-series union analysis for the UK.

17 In 1984, the Conservative government ended the right to trade union membership at GHCQ, arguing that it conflicted with national security interests - there had been a strike 
at the center in 1981, and fourteen workers were duly dismissed for refusing to give up their membership.

${ }^{18}$ Gosling and Lemieux (2001, Table 3) estimate that the minimum wage, applied to the 1998 distribution, would have reduced the variance of the distribution by 2 per cent for men, and by 6 per cent for women.

${ }^{19}$ Using the ONS central estimate from April 2001 NES and LFS, 29.8 per cent of the workforce aged 18-21 years fell below the adult NMW of $£ 4.10$.

20 Also, subject to agreement, unions can extend the validity of industrial action ballots from four to eight weeks; the resumption of industrial action after its suspension does not require the usual seven-days notice to the employer; and the courts are to have greater discretion in disregarding accidental failures in the organisation of ballots for industrial action.

21 Other aspects of the union legislation that merit mention include the banning of employer blacklists of union activists and the dismissal of union activists, as well as the abandonment of the requirement for periodic ballots for the deduction of union dues from the payroll.

22 The principal exception is the entitlement of shop stewards who advise union members about their training ('learning representatives') to paid time off to carry out their duties, including their own training .

${ }^{23}$ The increase in the length of paid maternity leave is material - from 18 to 26 weeks and the increase in statutory pay (paid for the last 20 weeks) is a little under two-thirds, but the employer can recover most of the cost.

24 For a formal statement on New Labour's third way as applied to industrial relations, see Undy (1999).

${ }^{25}$ For the union position on partnership at the workplace, see TUC (1999).

26 The five areas where qualified majority voting apply under the ASP are: health and safety, working conditions, information and consultation rights of workers, gender equality, and the integration of persons excluded from the labour market. Unanimity is stipulated in respect of dismissals protection, freedom of association, conditions of employment for third-country nationals resident in the Community, social security provisions, and financial contributions for manpower instruments; but under the December 2000 Treaty of Nice there has been a further extension of qualified majority voting to cover the first three of these areas.

27 The social partners on the employer side are UNICE and CEEP. UNICE is the French acronym for the Union of Industrial and Employers' Confederations of Europe and CEEP 
is its public sector counterpart, the European Centre of Public Enterprises. The union side is represented through the ETUC or European Trade Union Confederation.

${ }^{28}$ See Teulings and Hartog (1998, p. 308) and Chapters 6 and 14 of this volume on the "costs of decentralisation". A contrary view is offered by Siebert $(2002$, p. 8), who points out that corporatist countries generate poor employment performance if we link high levels of collective agreement coverage, taxes, and employment protection legislation to corporatism.

29 Thus, among other things, it secured adoption in Council of the posted workers directive as well as updates to earlier Community legislation dealing with collective dismissals and workers' rights in the event of company transfers (see below).

30 Note that the EU working time mandate (Directive 93/104/EC of 23.11.93) implemented by the new government in October 1998 is not ASP legislation but rather social charter legislation, with an implementation date of 23 November 1996. Having abstained from the vote in Council, the UK challenged the treaty base (viz. health and safety) of the legislation. This action was rejected by the European Court of Justice in November 1996. The transposition of the terms of the directive into national law was delayed by the election. The domestic legislation is in the form of The Working Time Regulations 1998 (SI 1998, No. 1833).

31 As a practical matter, this does not involve any substantive amendments to the 1977 legislation (Directive 77/187/EEC of 14.2.77) as amended in 1998 (Directive 98/50/EC of 29.6.98).

32 Interestingly, while 111 UK-based undertakings are estimated to be affected by the British enabling legislation, almost as many British multinationals appear to have been covered by the earlier EU legislation by virtue of the scale of their operations in continental Europe while the vast majority of non-UK based multinationals with operations in the UK included their British employees (see Addison and Belfield, 2002c).

33 That said, works councils could admittedly conflict with the traditional trade union principle of single channel communication (see Addison et al., 2000, p. 11).

34 Roger Lyons is General-Secretary of Amicus, the UK's second biggest union. The union was formed by the amalgamation of the MSF and AEEU. 


\section{References}

ACAS (1981), Annual Report 1980, London: Advisory Conciliation and Arbitration Service.

Addison, John T. (2000), 'European Union Labor Market Directives and Initiatives', in Samuel Estreicher (ed.), Global Competition and the American Employment Landscape As We Enter the $21^{\text {st }}$ Century, Boston, Mass.: Kluwer Law International, pp. 691-738.

Addison, John T., and Clive R. Belfield (2001), 'Updating the Determinants of Firm Performance: Estimation using the 1998 WERS', British Journal of Industrial Relations, 39 (2), 341-366.

Addison, John T., and Clive R. Belfield (2002a), 'Unions and Establishment Performance: Evidence from the British Workplace Industrial/Employment Relations Surveys', IZA Discussion Paper No. 455, Bonn: Institute for the Study of Labor, March.

Addison, John T., and Clive R. Belfield (2002b), 'Unions and Employment: The One Constant?', IZA Discussion Paper No. 479, Bonn: Institute for the Study of Labor, April.

Addison, John T., and Clive R. Belfield (2002c), 'What Do We Know About the New European Works Councils? Some Preliminary Evidence from Britain', Scottish Journal of Political Economy, 49 (4), 1-27.

Addison, John T., John S. Heywood, and Xiangdong Wei (2001), 'Unions and Plant Closings in Britain: New Evidence from the WERS Panel', IZA Discussion Paper No. 352, Bonn: Institute for the Study of Labor, August.

Addison, John T., and W. Stanley Siebert (1991), 'The Social Charter of the European Community: Evolution and Controversies', Industrial and Labor Relations Review, 44 (4), 597-625.

Addison, John T., and W. Stanley Siebert (1994), 'Recent Developments in Social Policy in the New European Union', Industrial and Labor Relations Review, 48 (1), 5-27.

Addison, John T., and W. Stanley Siebert (1998), 'Union Security in Britain', Journal of Labor Research, 19 (3), 495-517

Addison, John T., and W. Stanley Siebert (2001), 'Union Security in Britain with an Addendum on New Labour's Reforms,' in Samuel Estreicher, Harry Katz, and Bruce E. Kaufman (eds.), The Internal Governance and Organizational Effectiveness of Labor Unions: Essays in Honor of George Brooks, New York: Kluwer Law International, pp. 249-278.

Addison, John T., W. Stanley Siebert, Joachim Wagner, and Xiangdong Wei (2000), 'Worker Participation and Firm Performance: Evidence from Germany and Britain', British Journal of Industrial Relations, 38(1), 7-48. 
Blanchflower, David G., and Richard B. Freeman (1994), 'Did Mrs. Thatcher's Reforms Change British Labour Market Performance?' In Ray Barrell (ed.), The U.K. Labour Market - Comparative Aspects and Institutional Developments, Cambridge: Cambridge University Press, 1994, pp. 51-92.

Blanchflower, David G., Neil Millward, and Andrew J. Oswald (1991), 'Unionism and Employment Behaviour', Economic Journal, 101 (407), 815-834.

Booth, Alison L., and Andrew McCulloch (1999), 'Redundancy Pay, Unions and Employment', Manchester School, 67 (3), 346-366.

Brown, William (2000), 'Putting Partnership into Practice in Britain', British Journal of Industrial Relations, 38 (2), 299-316.

Brown, William A., Simon Deakin, and Paul Ryan (1997), 'The Effects of British Industrial Relations Legislation', National Institute Economic Review, 161, 69-83.

Brown, William, Simon Deakin, David Nash, and Sarah Oxenbridge (2000), 'The Employment Contract: From Collective Procedures to Individual Rights,' British Journal of Industrial Relations, 38 (4), 611-629.

Bryson, Alex (2001), 'Unions and Workplace Closure in Britain, 1990-98', Unpublished Paper, London: Policy Studies Institute, October.

Bryson, Alex (2002), 'The Union Membership Premium: An Analysis Using Propensity Score Matching', Unpublished Paper, London: Policy Studies Institute, January.

Card, David (1998), 'Falling Union Membership and Rising Wage Inequality: What's the Connection?', NBER Working Paper 6520, Cambridge, Mass.: National Bureau for Economic Research.

Card, David, and Richard B. Freeman (2002), 'What Have Two Decades of British Economic Reform Delivered?', in Richard Blundell, David, Card, and Richard B. Freeman (eds), Seeking a Premier League Economy, Chicago, Ill.: University of Chicago Press for NBER, pp. _ (to be added on publication).

Commission (2000), 'Communication from the Commission to the Council, the European Parliament, the Economic and Social Committee and the Committee of the Regions Social Policy Agenda', COM (2000) 379 final, Brussels: Commission of the European Communities.

Commission (2001a), 'Communication from the Commission to the Council, The European Parliament and the Economic and Social Committee - Promoting Core Labour Standards and Improving Social Governance in the Context of Globalisation', COM (2001) 416 final. Brussels: Commission of the European Communities, 18.7.2001. 
Commission (2001b), 'Promoting a European Framework for Corporate Social Responsibility - Green Paper'. Luxembourg: Office for Official Publications for the European Communities.

Conyon, Martin J., and Richard B. Freeman (2001), 'Shared Modes of Compensation and Firm Performance: U.K. Evidence', NBER Working Paper 8448, Cambridge, Mass.: National Bureau of Economic Research, August.

Coutts, Ken, Roger Tarling, Terry Ward, and Frank Wilkinson (1981), 'The Economic Consequences of Mrs. Thatcher,' Cambridge Journal of Economics, 5 (1), 81-93.

Cully, Mark, Stephen Woodland, Andreew O'Reilly, and Gill Dix (199), Britain at Work: As Depicted by the 1998 Workplace Employment Relations Survey, London: Routledge.

Davies, Paul, and Mark Freedland (1993), Labour Legislation and Public Policy, Oxford: Clarendon Press.

Deakin, Simon, and Gillian S. Morris (1995), Labour Law, London: Butterworths.

Department of Trade and Industry (1998), Fairness at Work, London: HMSO, Cm 3968, May.

Department of Trade and Industry (2001a), Routes to Resolution: Improving Dispute Resolution in Britain, London: DTI.

Department of Trade and Industry (2001b), The Government Response, London: DTI.

Department of Trade and Industry (2002), High Performance Workplaces - the Role of Employee Involvement in a Modern Economy, Discussion Paper, London: DTI, July.

Disney, Richard, Amanda Gosling, and Stephen Machin (1995), 'British Unions in Decline: Determinants of the 1980s Fall in Union Recognition'. Industrial and Labor Relations Review, 48 (3), 403-419.

Donovan Commission (1968), Royal Commission on Trade Unions and Employers' Associations, Cmnd. 3623, London:HMSO.

Dunn, Stephen, and David Metcalf (1996), 'Trade Union Law Since 1979', in Ian Beardwell, ed., Contemporary Industrial Relations: A Critical Analysis, Oxford: Oxford University Press, pp. 66-98.

EIRR (2000a), 'European Works Councils Update', European Industrial Relations Review, (316), 20-22.

EIRR (2000b), 'Commission Issues EWCs Report', European Industrial Relations, (317), pp. 19-22. 
EIRR (2000c), 'Draft EU Charter of Fundamental Rights Agreed', European Industrial Relations Review, (322), 124-19.

EIRR (2001), 'Union Recognition Increasing', European Industrial Relations Review, (327), 2427.

Employment Department (1995), 'Labour Disputes in 1994', Employment Gazette, 103 (7), 279-289.

Fernie, Sue, and David Metcalf (1995), 'Participation, Contingent Pay, Representation and Workplace Performance: Evidence from Great Britain', British Journal of Industrial Relations, 33 (3), 379-415.

Freeman, Richard B. (1980), 'Unionism and the Dispersion of Wages', Industrial and Labor Relations Review, 34 (1), 3-23.

Freeman, Richard B., and Jeffrey Pelletier (1990), 'The Impact of Industrial Relations Legislation on British Union Density, British Journal of Industrial Relations, 29 (2), 141-164.

Gosling, Amanda and Thomas Lemieux (2001), 'Labor Market Reforms and Changes in Wage Inequality in the United Kingdom and the United States', NBER Working Paper 8413, Cambridge, Mass.: National Bureau of Economic Research (August).

Gosling, Amanda, Stephen Machin, and Costas Meghir (2000), 'The Changing Distribution of Male Wages in the U.K.', Review of Economic Studies, 67 (4), 635-666.

Gregg, Paul, Stephen Machin, and David Metcalf (1993), 'Signals and Cycles? Productivity Growth and Changes in Union Status in British Companies, 1984-9', Economic Journal, 103 (419), 894-907.

Hendy, John (1993), A Law Unto Themselves: Conservative Employment Laws, London: Institute of Employment Rights.

Hendy, John (2001), Union Rights ... And Wrongs: The Reform of Britain's Anti-Union Laws, London: Institute of Employment Rights.

Hirsch, Barry T., and John T. Addison (1986), The Economic Analysis of Unions - New Approaches and Evidence, London and Boston: Allen \& Unwin.

Industrial Relations Services (1999), 'Now We Are Two', Employment Trends, 679, 224.

Labour Research Department (1999), 'Minimum Wage Becomes A Reality', Labour Research, 88 (4), 11-12.

Labour Research Department (2001), 'Has New Labour Satisfied Unions?', Labour Research, 90 (6), 12-14. 
Low Pay Commission (2001). The National Minimum Wage: Making a Difference, Third Report, London: Low Pay Commission.

Machin, Stephen, Alan Manning, and Lupia Rahman (2002), 'Where the Minimum Wage Bites Hard: The Introduction of the UK National Minimum Wage to a Low Wage Sector, Unpublished Paper, Department of Economics, University College London.

Lanot, Guy, and Ian Walker (1998), 'The Union/Nonunion Wage Differential: An Application of Semi-Parametric Methods', Journal of Econometrics, 84 (2), 327-349.

Lyons, Roger (2002), 'Partners in Productivity', Financial Times, 30 July, p. 15.

Machin, Stephen (1991), 'The Productivity Effects of Unionism and Firm Size in British Engineering Firms', Economica, 58 (232), 479-490.

Machin, Stephen (1995), 'Plant Closures and Unionization in British Establishmnents', British Journal of Industrial Relations, 33 (1), 55-68.

Machin, Stephen (1997), 'The Decline of Labour Market Institutions and the Rise in Wage Inequality in Britain', European Economic Review, 41 (3-5), 647-657.

Machin, Stephen (2000), 'Union Decline in Britain', British Journal of Industrial Relations, 38 (4), 631-645.

Machin, Stephen (2001), 'Does It Still Pay to be in or to Join a Union', Unpublished Paper, Department of Economics, University College London.

Machin, Stephen, Alan Manning, and Lupia Rahman (2002), 'Where the Minimum Wage Bites Hard: The Introduction of the UK National Minimum Wage to a Low Wage Sector, Unpublished Paper, Department of Economics, University College London.

Machin, Stephen, and Mark Stewart (1996), ' Trade Unions and Financial Performance', Oxford Economic Papers, 48 (2), 213-241.

Machin, Stephen, and S. Wadhwani (1991), ' The Effects of Unions on Organisational Change and Employment', Economic Journal, 101 (407), 835-854.

Manning, Alan (1993), 'Pre-Strike Ballots and Wage-Employment Bargaining', Oxford Economic Papers, 45 (3), 422-439.

Marsden, David (1985), 'Chronicle - Industrial Relations in the UK, August-November 1984', British Journal of Industrial Relations, 23 (1),139-158.

McKay, Sonia (1996), The Law on Industrial Action Under the Conservatives. London: Institute of Employment Rights. 
Menezes-Filho, Naercio (1997), 'Unions and Profitability over the 1980s: Some Evidence on Union-Firm Bargaining in the United Kingdom', Economic Journal, 107 (442), 651670 .

Metcalf, David (1993), 'Industrial Relations and Economic Performance', British Journal of Industrial Relations, 31 (2), 255-283.

Millward, Neil, David Smart, and W. Hawes (1992), Workplace Industrial Relations in Transition, Aldershot: Dartmouth.

Minford, Patrick, and Andrew Haldenby (1999), 'The Price of Fairness - The Cost of the Proposed Labour Market Reforms,' London: Centre for Policy Studies, June.

Moreton, David (1999), 'A Model of Labor Productivity and Union Density in British Private Sector Unionized Establishments', Oxford Economic Papers, 51 (2), 322-344.

ONS (2001), 'Labour Disputes in 2000', Labour Market Trends, 109 (6), 301-314.

ONS (2002), Measuring Low Pay, London: Office of National Statistics website http://www.statistics.gov.uk/themes/labour market/pay and earnings/

measuring low pay.asp.

Oulton, Nicholas (1990), 'Labour Productivity in U.K. Manufacturing in the 1970s and the 1980s', National Institute Economic Review, 132, 71-91.

Pencavel, John H. (2002), 'The Surprising Retreat of Union Britain,' in Richard Blundell, David Card, and Richard B. Freeman (eds), Seeking a Premier League Economy, Chicago, Ill.: University of Chicago Press for NBER, pp. _ (to be added on publication).

Schmitt, John (1995), 'The Changing Structure of Male Earnings in Britain, 1974-1988', in Richard B. Freeman and Lawrence F. Katz (eds.), Differences and Changes in Wage Structures, Chicago, Ill.: University of Chicago Press, pp. 177-204.

Siebert, W. Stanley, and John T. Addison (1981), 'Are Strikes Accidental?' Economic Journal, 91 (362), 389-404.

Siebert, W. Stanley (2002), 'Notes on Labour Market Flexibility', Unpublished Paper, Department of Commerce, Birmingham University.

Smith, Paul, and Gary Morton (2001), New Labour's Reform of Britain's Employment Law: The Devil is not only in the Detail but in the Values and Policy Too', British Journal of Industrial Relations, 39 (1), 119-138.

Stewart, Mark (1987), 'Collective Bargaining Agreements, Closed Shops and Relative Pay', Economic Journal, 97 (385) 140-156. 
Stewart, Mark (1995), 'Union Wage Differentials in an Era of Declining Unionisation', Oxford Bulletin of Economics and Statistics, 57 (2), 143-166.

Stewart, Mark (2001), 'The Impact of the Introduction of the UK Minimum Wage on the Employment Probabilities of Low Wage Workers', Unpublished Paper, Department of Economics, University of Warwick.

Stewart, Mark (2001), 'The Impact of the Introduction of the UK Minimum Wage on the Employment Probabilities of Low Wage Workers', Unpublished Paper, Department of Economics, University of Warwick.

Studdard, Nigel, and James Jenkins (2001), 'Measuring Low Pay Using the New Earnings Survey and the Labour Force Survey', Labour Market Trends, 109 (1), 55-66.

Teulings, Coen, and Joop Hartog (1998), Corporatism or Competition? Labour Contracts, Institutions, and Wage Structures in International Comparison, Cambridge: Cambridge University Press.

TUC (1999), Partners for Progress: New Unionism at the Workplace, London: Trade Union Congress, October.

TUC (2000), Trade Union Trends: Focus on Recognition, London: Trade Union Congress, January.

TUC (2001), Trade Union Trends: Focus on Recognition, London: Trade Union Congress, January.

Undy, Roger (1999), 'New Labour's 'Industrial Relations Settlement": the Third Way', British Journal of Industrial Relations, 37 (2), 315-336.

Wood, Stephen, and John Godard (1999), 'The Statutory Union Recognition Procedure in the Employment Relations Bill: A Comparative Analysis', British Journal of Industrial Relations, 37 (2), 203-244. 
Table 1

The Course of Union Legislation

Legislation

Content

1974 and 1976 Trade Union \& Labour Relations

Acts

1975,

Employment

Protection Act

1980,

Employment Act

1982,

Employment Act

1984, Trade

Union Act

1988 ,

Employment Act

1990,

Employment Act
Repealed the right not to be a union member (except for genuine religious belief). Where a firm and a union negotiate a union membership agreement (closed shop), dismissal of workers for non-membership of union deemed fair. Also, worker had no right to appeal to Industrial Tribunal when dismissed for non-membership in union.

Tightened unfair dismissal rights. Established a Trade Union Certification Officer to certify union independence from management. Established an Advisory, Conciliation and Arbitration (ACAS) Service to investigate, report, and make recommendations for union recognition. Also set up Central Arbitration Committee with enforcement role in recognition procedure and to hear claims from unions in support of extension of terms and conditions of collective agreements.

Statutory union recognition procedures abolished. New union membership agreements required to be approved in secret ballot by at least 80 per cent of those entitled to vote. Immunity from damages in tort withdrawn from union officials in cases of secondary industrial action, including action to compel union membership. Fund established to reimburse unions for postal secret ballots on industrial action and union elections. Picketing away from own workplace made unlawful.

All union membership agreements required to be approved in secret ballot every five years, again by not less than 80 per cent of those e ntitled to vote, or 85 per cent of those voting. Punitive compensation of up to $£ 20,000$ to be awarded to workers unfairly dismissed on grounds of non-membership in unions. Contracts requiring union-only labour to be unlawful, as well as tenders awarded on a basis of union-only labour. Trade union funds no longer automatically sheltered from liability for damages in tort with narrowing of immunities.

Damages in any proceedings set at up to $£ 250,000$ for unions with more than 100,000 members. Fair Wages Resolution (requiring government contractors to pay union rates) rescinded.

Secret ballots (either postal or workplace) required prior to industrial action; postal ballot expenses to be reimbursed by the Certification Officer. Alsosecret ballots required for union executive elections every five years and political funds every ten years.

Established a Commissioner for the Rights of Trade Union Members (CROTUM) to assist union members with advice and in applications to the High Court. Union members given the right not to be disciplined by their union for failure to support industrial action. Remedies available to union from their union set at up to $£ 8,500$. It became automatically unfair to dismiss a worker for non-membership of a union irrespective of whether the closed shop had been supported by a ballot. Industrial action to impose a closed shop lost immunity from tort liability.

It was now unlawful to discriminate against non-union members (or union members) at the time of recruitment. Job advertisements could not specify union membership. Any practice under which employment was afforded only to union members presumed to be discriminatory. Unions had to repudiate unofficial industrial action; unofficial strikers could be summarily dismissed; and immunity for industrial action in support of dismissed strikers removed. 
1993, Trade

Union and

Employment

Rights Act

1999 ,

Employment

Relations Act
No union could refuse to accept anyone into membership (or expel anyone) unless on grounds of the individual's conduct. The union dues check-off to be authorized in writing by each member every three years. Established a Commissioner for Protection against Unlawful Industrial Action (COPUIA) to advise and finance individuals claiming to have been affected by unlawful industrial action who could apply to the High Court for an order against the union to discontinue that action. Tighter restrictions on strike ballots. Wages Councils abolished.

Establishes a statutory union recognition procedure for firms employing more than 20 workers; makes it automatically unfair to dismiss strikers during first 8 weeks of industrial action; weakens strike balloting rules; and gives the right to be accompanied by a union official in disciplinary interviews. The penalty for unfair dismissal also raised from $£ 12,000$ to $£ 50,000$. CROTUM and COPUIA abolished.

Note: See text. 
Table 2

Trade Union Membership Rates, 1983 and 1995

\begin{tabular}{|c|c|c|c|c|c|c|}
\hline & \multicolumn{3}{|c|}{ Men } & \multicolumn{3}{|c|}{ Women } \\
\hline & 1983 & 1995 & $\begin{array}{l}\text { Ratio } \\
95 / 83 \\
\end{array}$ & 1983 & 1995 & $\begin{array}{l}\text { Ratio } \\
95 / 83 \\
\end{array}$ \\
\hline $\begin{array}{l}\text { Overall } \\
\text { By education: }\end{array}$ & 56.7 & 36.0 & .64 & 42.1 & 29.8 & .71 \\
\hline $\begin{array}{l}\text { Degree or } \\
\text { equivalent }\end{array}$ & 51.4 & 40.1 & .78 & 61.7 & 48.2 & .79 \\
\hline Further education & 59.9 & 41.7 & .70 & 65.1 & 59.2 & .91 \\
\hline $\begin{array}{l}\text { 'A' level or } \\
\text { equivalent }\end{array}$ & 54.1 & 36.7 & .68 & 42.0 & 26.5 & .63 \\
\hline $\begin{array}{l}\text { 'O' level or } \\
\text { equivalent }\end{array}$ & 46.2 & 24.2 & .52 & 33.5 & 22.8 & .68 \\
\hline Other & 57.9 & 40.3 & .70 & 33.1 & 22.4 & .68 \\
\hline None & 62.5 & 32.9 & .53 & 43.5 & 21.1 & .49 \\
\hline \multicolumn{7}{|l|}{ By age (years): } \\
\hline $16-30$ & 44.1 & 22.7 & .52 & 36.6 & 21.4 & .58 \\
\hline $31-55$ & 62.3 & 42.0 & .68 & 45.0 & 34.3 & .76 \\
\hline $56-66$ & 65.9 & 39.5 & .61 & 45.6 & 26.5 & .58 \\
\hline \multicolumn{7}{|l|}{ By colour: } \\
\hline White & 56.4 & 36.0 & .64 & 42.1 & 29.6 & .70 \\
\hline Nonwhite & 67.4 & 27.6 & .41 & 46.8 & 28.9 & .62 \\
\hline \multicolumn{7}{|l|}{ By region: } \\
\hline North & 64.9 & 43.4 & .67 & 48.3 & 35.2 & .73 \\
\hline Midlands & 57.6 & 37.3 & .65 & 46.8 & 27.0 & .58 \\
\hline South, incl. London & 49.1 & 29.1 & .59 & 32.0 & 24.4 & .76 \\
\hline Wales & 65.0 & 48.9 & .77 & 52.8 & 38.8 & .73 \\
\hline Scotland & 63.5 & 38.0 & .60 & 55.7 & 37.7 & .68 \\
\hline \multicolumn{7}{|l|}{ By sector: } \\
\hline Private & 41.5 & 27.2 & .63 & 25.8 & 14.7 & .57 \\
\hline Public & 85.0 & 65.7 & .78 & 69.0 & 58.3 & .84 \\
\hline Observations & 4483 & 3966 & & 3580 & 4054 & \\
\hline
\end{tabular}

Notes: Samples are taken from the 1983 General Household Survey and the 1995 third quarter Labour Force Survey. Samples include respondents aged 16-66 years, who were not self-employed and whose hourly wage was between $£ 1$ and $£ 45$ in 1995 pounds (1983 wages valued in 1995 pounds according to the retail price index). 
Table 3

Wage Distributions of Union and Non-Union Workers, 1983 and 1995

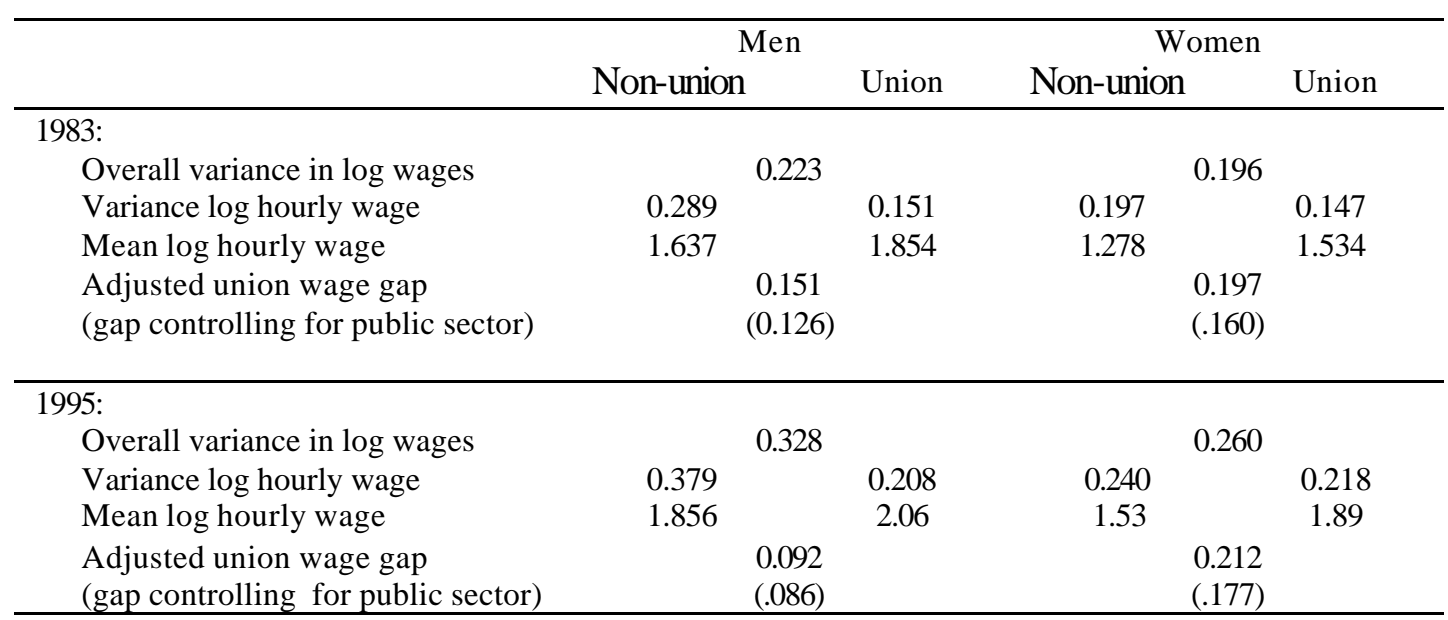

Notes: The adjusted union wage gap is the union coefficient from a regression controlling for years of education, years of experience (plus experience squared and cubed), and dummies for non-white, marital status, and 5 regions (plus a dummy for public sector employment in the case of the bracketed coefficient). See notes to Table 2 for sample and hourly wage definitions.

Sources: see Table 2. 
Table 4

Simple Estimates of the Contribution of Declining Unionisation to Wage Inequality 1983-95

\begin{tabular}{|c|c|c|c|}
\hline & Men & Women & Remarks \\
\hline \multicolumn{4}{|l|}{ 1983: } \\
\hline Union density, U & .567 & .421 & From Table 2. \\
\hline Union wage gap, ?W & .151 & .197 & $\begin{array}{l}\text { Difference between union and non-union wages } \\
\text { (Table 3). }\end{array}$ \\
\hline Union variance gap, ? V & -.138 & -.050 & $\begin{array}{l}\text { Difference in union and non-union wage variances } \\
\text { (Table 3). }\end{array}$ \\
\hline $\begin{array}{l}\text { Union effect, between } \\
\text { sectors, } \mathrm{U}(1-\mathrm{U}) \text { ? } \mathrm{W}^{2}\end{array}$ & .006 & .009 & $\begin{array}{l}\text { Small effect of unions in raising wage inequality } \\
\text { by widening mean pay as between union and non- } \\
\text { union sectors. }\end{array}$ \\
\hline $\begin{array}{l}\text { Union effect, within } \\
\text { sectors, U? V }\end{array}$ & -.078 & -.021 & $\begin{array}{l}\text { Larger effect of unions is to reduce wage } \\
\text { dispersion within union sectors. }\end{array}$ \\
\hline Total effect & -.072 & -.012 & $\begin{array}{l}\text { Estimated total effect of unions is to reduce wage } \\
\text { variance; for example, for men the reduction is } \\
-.072 \text {. }\end{array}$ \\
\hline \multicolumn{4}{|l|}{1995} \\
\hline Union density, U & .360 & .298 & From Table 2. \\
\hline Union wage gap, ?W & .092 & .212 & From Table 3. \\
\hline Union variance gap, ? V & -.171 & -.022 & From Table 3. \\
\hline Union effect, between & .002 & .009 & \\
\hline $\begin{array}{l}\text { Union effect, within } \\
\text { sectors, U? V }\end{array}$ & -.062 & -.007 & See explanations for 1983 above. \\
\hline Total effect & -.060 & .002 & $\begin{array}{l}\text { Variance-reducing effect of unions is smaller in } \\
1995 \text { than 1983, and women's unions even } \\
\text { increase dispersion in } 1995 \text {. }\end{array}$ \\
\hline \multicolumn{4}{|l|}{ Changes 1983-95 } \\
\hline $\begin{array}{l}\text { Change in variance of } \\
\text { wages }\end{array}$ & .105 & .064 & See Table 3; for example, for men $.105=.328-.223$. \\
\hline $\begin{array}{l}\text { Change in effect of } \\
\text { unions }\end{array}$ & .012 & .014 & $\begin{array}{l}\text { Change in total effect derived above: for example, } \\
\text { for men, } .012=-.060-(-.072)\end{array}$ \\
\hline $\begin{array}{l}\text { Contribution of unions } \\
(\%)\end{array}$ & 11.4 & 21.9 & $\begin{array}{l}\text { For example, for men, } .114=.012 / .105 \text {. Effect of } \\
\text { decline in unionisation for women is larger than for } \\
\text { men, mainly because variance gap has declined so } \\
\text { much for women. }\end{array}$ \\
\hline
\end{tabular}

Notes: See text for formulae. 
Table 5

Adjusted Estimates of the Contribution of Declining Unionisation to Wage Inequality, Allowing for Different Union Effects Across Pay Deciles

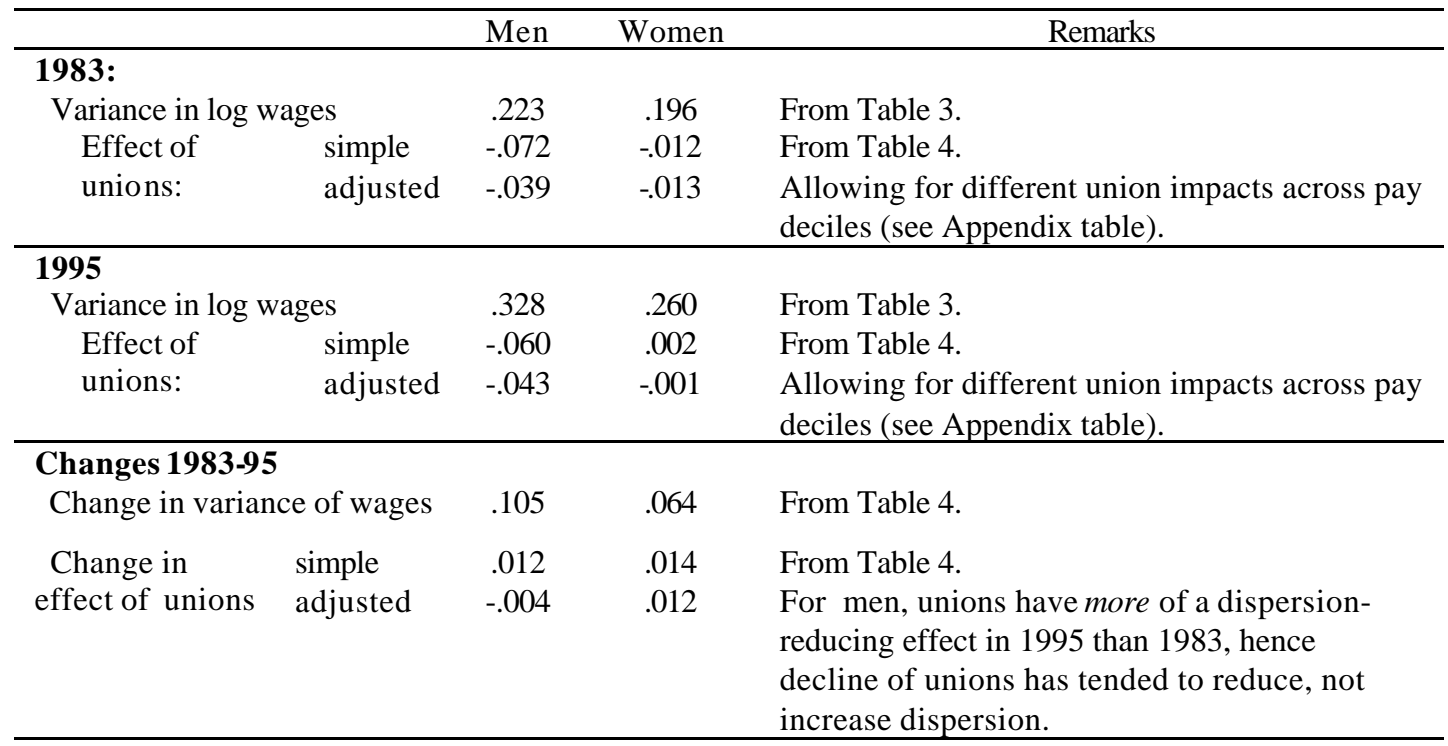

Notes: The adjusted formula (allowing for different union effects by skill category) for the effect of unions on the variance of wages $(\mathrm{V})$ relative to the variance if all workers were paid according to the non-union sector wage structure $\left(\mathrm{V}^{*}\right)$ is given in Card (1998, p. 5) as:

$\mathrm{V}-\mathrm{V}^{*}=\mathrm{E}[\mathrm{u}(\mathrm{c}) ? \mathrm{v}(\mathrm{c})]+\mathrm{E}\left[\mathrm{u}(\mathrm{c})(1-\mathrm{u}(\mathrm{c})) ? \mathrm{w}(\mathrm{c})^{2}\right]+\mathrm{var}[\mathrm{u}(\mathrm{c}), ? \mathrm{w}(\mathrm{c})]+2 \operatorname{cov}\left[\mathrm{W}_{\mathrm{N}}(\mathrm{c}), \mathrm{u}(\mathrm{c}) ? \mathrm{w}(\mathrm{c})\right]$,

where $u(c)$ is the distribution of union density across the c skill categories, ?v(c) is the distribution of variance gaps, ? $\mathrm{w}(\mathrm{c})$ is the distribution of wage gaps and $\mathrm{W}_{\mathrm{N}}(\mathrm{c})$ is the distribution of non-union wage rates. Values, calculated from the data in the Appendix Table, are as follows:

\begin{tabular}{lcccc}
\hline & & Men & & Women \\
& 1983 & 1995 & 1983 & 1995 \\
$\mathrm{E}[\mathrm{u}(\mathrm{c}) ? \mathrm{v}(\mathrm{c})]$ & -.025 & -.034 & -.027 & -.023 \\
$\mathrm{E}\left[\mathrm{u}(\mathrm{c})(1-\mathrm{u}(\mathrm{c})) ? \mathrm{w}(\mathrm{c})^{2}\right]$ & .009 & .004 & .011 & .009 \\
$\operatorname{var}[\mathrm{u}(\mathrm{c}), ? \mathrm{w}(\mathrm{c})]$ & .003 & .001 & .001 & .001 \\
$2 \operatorname{cov}\left[\mathrm{W}_{\mathrm{N}}(\mathrm{c}), \mathrm{u}(\mathrm{c}) ? \mathrm{w}(\mathrm{c})\right]$ & -.026 & -.014 & .002 & .012 \\
Total & $\mathbf{- . 0 3 9}$ & $\mathbf{- . 0 4 3}$ & $\mathbf{- . 0 1 3}$ & $\mathbf{. . 0 0 1}$ \\
\hline
\end{tabular}


Table 6

Estimates of Workers Whose Pay is Raised by the NMW

\begin{tabular}{llll}
\hline $\begin{array}{l}\text { Date of } \\
\text { minimum } \\
\text { wage law }\end{array}$ & $\begin{array}{l}\text { Level } \\
\text { (age group) }\end{array}$ & $\begin{array}{l}\text { Coverage } \\
\text { estimate, } \\
\text { '000s (per cent } \\
\text { of group) }\end{array}$ & \\
\hline April 1999 & $£ 3.60(22+)$ & $1401(6.4 \%)$ & Estimate by Low Pay Commission (2001, \\
& $£ 3.00(18-21)^{\mathrm{a}}$ & $122(7.7)$ & $\begin{array}{l}\text { Table A1.1) using ONS central estimate } \\
\text { from April 1998 NES and LFS }\end{array}$ \\
Oct 2000 & $£ 3.70(22+)$ & $856(3.8)$ & $\begin{array}{l}\text { Estimate using ONS central estimate from } \\
\text { April 2000 NES and LFS }\end{array}$ \\
& $£ 3.20(18-21)$ & $81(4.8)$ & $\begin{array}{l}\text { Aprim } \\
\text { Oct 2001 }\end{array}$ \\
& $£ 4.10(22+)$ & $1611(7.0)$ & $\begin{array}{l}\text { Estimate using ONS central estimate from } \\
\text { April 2001 NES and LFS }\end{array}$ \\
\hline
\end{tabular}

Notes: ${ }^{\text {a }}$ Youth rate was subsequently raised to $£ 3.20$ in June 2000.

${ }^{\mathrm{b}}$ The Office of National Statistics (ONS) central estimate methodology using the April New Earnings Survey (NES) and the quarterly Labour Force Survey (LFS) is explained in Studdard and Jenkins (2001).

${ }^{\mathrm{c}}$ ONS central estimate low pay distributions for April 2000 and April 2001 are published at the ONS website (ONS, 2002). 


\section{Appendix Table \\ Union Membership Rates and Union Wage Effects by Pay Decile}

\begin{tabular}{|c|c|c|c|c|c|c|c|c|}
\hline \multicolumn{5}{|c|}{1983} & \multicolumn{3}{|c|}{1995} & \\
\hline \multicolumn{9}{|l|}{ Men } \\
\hline $\begin{array}{l}\text { Predicted } \\
\text { wage } \\
\text { decile }\end{array}$ & $\begin{array}{c}\text { Percent } \\
\text { union }\end{array}$ & $\log W_{N}$ & Wage gap & $\begin{array}{c}\text { Variance } \\
\text { gap }\end{array}$ & $\begin{array}{c}\text { Percent } \\
\text { union }\end{array}$ & $\log W_{N}$ & Wage gap & $\begin{array}{c}\text { Variance } \\
\text { gap }\end{array}$ \\
\hline 1 & 0.27 & 1.06 & 0.4 & -0.04 & 0.17 & 0.94 & 0.3 & -0.09 \\
\hline 2 & 0.61 & 1.41 & 0.29 & -0.01 & 0.54 & 1.14 & 0.16 & -0.04 \\
\hline 3 & 0.69 & 1.52 & 0.21 & -0.01 & 0.45 & 1.14 & 0.17 & 0.03 \\
\hline 4 & 0.63 & 1.55 & 0.21 & -0.03 & 0.44 & 1.17 & 0.19 & -0.03 \\
\hline 5 & 0.61 & 1.58 & 0.18 & -0.07 & 0.38 & 1.27 & 0.16 & -0.06 \\
\hline 6 & 0.56 & 1.67 & 0.12 & -0.02 & 0.34 & 1.27 & 0.16 & -0.06 \\
\hline 7 & 0.62 & 1.77 & 0.09 & -0.05 & 0.41 & 1.34 & 0.22 & -0.11 \\
\hline 8 & 0.56 & 1.87 & 0.08 & -0.04 & 0.34 & 1.4 & 0.22 & -0.04 \\
\hline 9 & 0.57 & 2.04 & 0.03 & -0.04 & 0.44 & 1.52 & 0.33 & -0.01 \\
\hline 10 & 0.57 & 2.29 & 0.03 & -0.14 & 0.62 & 1.85 & 0.12 & -0.19 \\
\hline \multicolumn{9}{|l|}{ Women } \\
\hline 1 & 0.11 & 1.19 & 0.28 & -0.06 & 0.15 & 1.22 & 0.18 & -0.06 \\
\hline 2 & 0.35 & 1.53 & 0.21 & -0.05 & 0.21 & 1.32 & 0.15 & -0.07 \\
\hline 3 & 0.34 & 1.68 & 0.13 & -0.09 & 0.27 & 1.37 & 0.18 & -0.04 \\
\hline 4 & 0.41 & 1.71 & 0.15 & -0.09 & 0.22 & 1.45 & 0.21 & -0.01 \\
\hline 5 & 0.41 & 1.84 & 0.15 & -0.07 & 0.24 & 1.53 & 0.17 & -0.05 \\
\hline 6 & 0.40 & 2.01 & 0.02 & -0.11 & 0.3 & 1.55 & 0.24 & -0.04 \\
\hline 7 & 0.39 & 2.02 & 0.08 & -0.05 & 0.23 & 1.63 & 0.16 & -0.06 \\
\hline 8 & 0.32 & 2.18 & 0.02 & -0.19 & 0.26 & 1.7 & 0.30 & -0.05 \\
\hline 9 & 0.39 & 2.4 & -0.02 & -0.008 & 0.45 & 1.87 & 0.31 & -0.12 \\
\hline 10 & 0.48 & 2.54 & 0.02 & -0.19 & 0.48 & 2.18 & 0.17 & -0.18 \\
\hline
\end{tabular}

Notes: Predicted pay decile is based on a prediction equation for the non-union sector, using an equation with years of education, experience, experience squared and cubed, dummies for marital status, non-white and five regions, and interaction of five levels of education with education and linear and quadratic experience. The wage gap is the difference between the log of hourly pay between union and non-union workers for the given decile. The variance gap is the difference in the variance of log pay between union and non-union workers for the given decile. 
Figure1: Males - Union membership by skill, 1983 and 1995

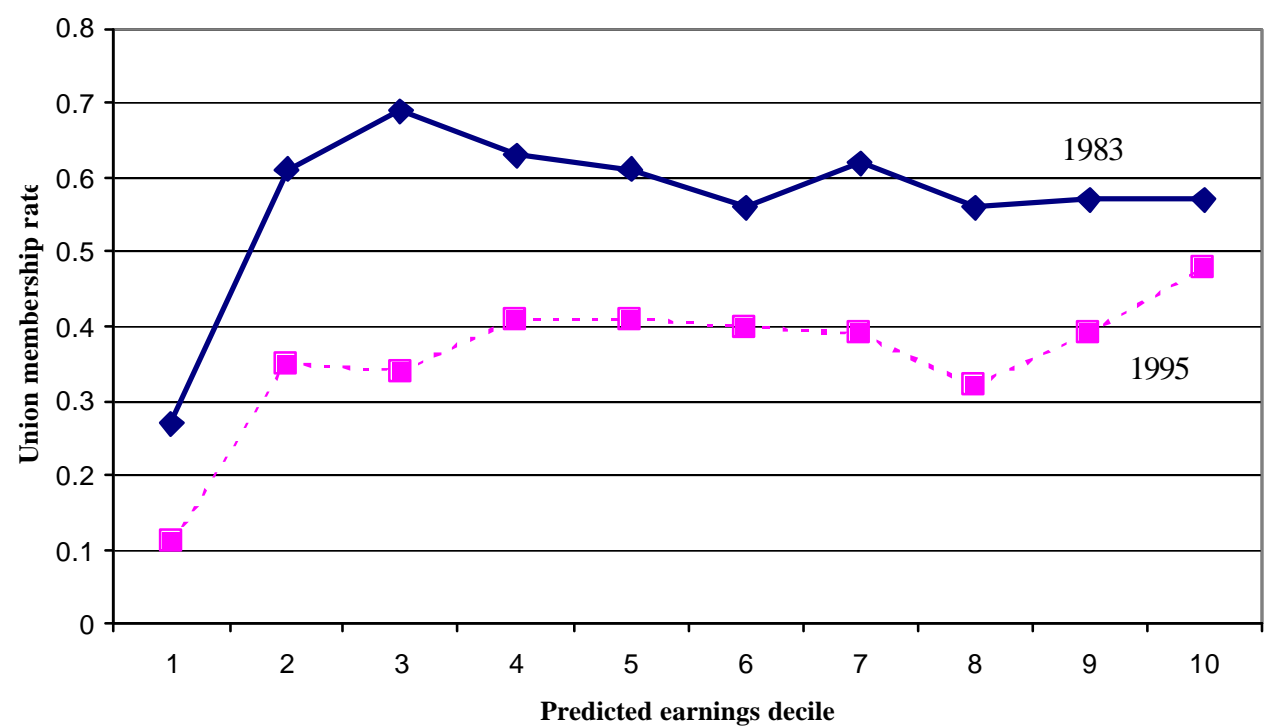

Figure 2: Females - Union membership by skill, 1983 and 1995

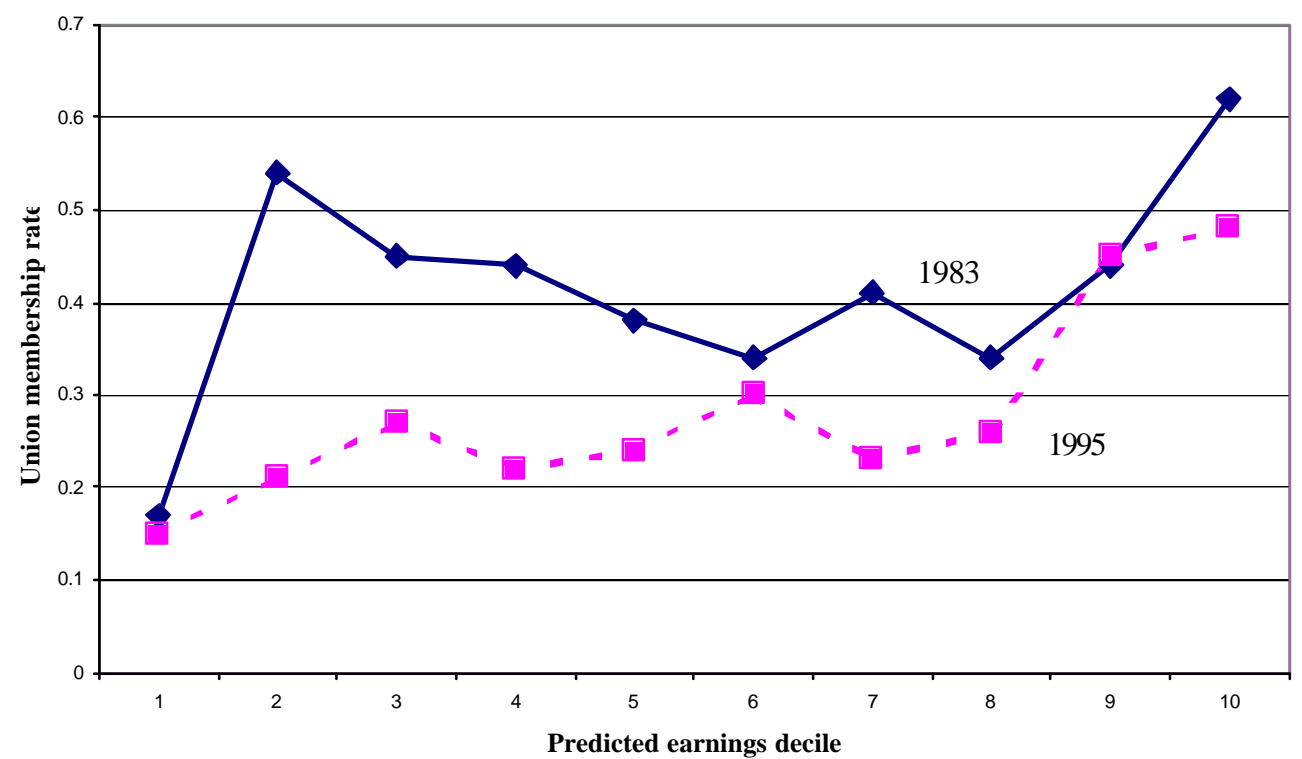




\section{IZA Discussion Papers}

\begin{tabular}{|c|c|c|c|c|}
\hline No. & Author(s) & Title & Area & Date \\
\hline 547 & $\begin{array}{l}\text { G. S. Epstein } \\
\text { I. N. Gang }\end{array}$ & $\begin{array}{l}\text { Government and Cities: Contests and the } \\
\text { Decentralization of Decision Making }\end{array}$ & 3 & 08/02 \\
\hline 548 & M. Frölich & $\begin{array}{l}\text { What is the Value of Knowing the Propensity } \\
\text { Score for Estimating Average Treatment } \\
\text { Effects? }\end{array}$ & 6 & $08 / 02$ \\
\hline 549 & E. Wasmer & $\begin{array}{l}\text { Interpreting Europe and US Labor Markets } \\
\text { Differences: The Specificity of Human Capital } \\
\text { Investments }\end{array}$ & 2 & $08 / 02$ \\
\hline 550 & D. Clark & $\begin{array}{l}\text { The Impact of Local Labour Market Conditions } \\
\text { on Participation in Further Education in England }\end{array}$ & 5 & $08 / 02$ \\
\hline 551 & $\begin{array}{l}\text { T. Bauer } \\
\text { G. Epstein } \\
\text { I. N. Gang }\end{array}$ & $\begin{array}{l}\text { Herd Effects or Migration Networks? } \\
\text { The Location Choice of Mexican Immigrants in } \\
\text { the U.S. }\end{array}$ & 1 & $08 / 02$ \\
\hline 552 & $\begin{array}{l}\text { R. Fahr } \\
\text { U. Sunde }\end{array}$ & $\begin{array}{l}\text { Estimations of Occupational and Regional } \\
\text { Matching Efficiencies Using Stochastic } \\
\text { Production Frontier Models }\end{array}$ & 6 & $08 / 02$ \\
\hline 553 & $\begin{array}{l}\text { S. Machin } \\
\text { P. A. Puhani }\end{array}$ & $\begin{array}{l}\text { Subject of Degree and the Gender Wage } \\
\text { Differential Evidence from the UK and Germany }\end{array}$ & 2 & $08 / 02$ \\
\hline 554 & W. Koeniger & $\begin{array}{l}\text { Employment Protection, Product Market } \\
\text { Competition and Growth }\end{array}$ & 3 & $08 / 02$ \\
\hline 555 & $\begin{array}{l}\text { D. J. DeVoretz } \\
\text { H. Hinte } \\
\text { C. Werner }\end{array}$ & $\begin{array}{l}\text { How much Language is Enough? Some } \\
\text { Immigrant Language Lessons from Canada and } \\
\text { Germany }\end{array}$ & 1 & $08 / 02$ \\
\hline 556 & $\begin{array}{l}\text { S. E. Black } \\
\text { E. Brainerd }\end{array}$ & $\begin{array}{l}\text { Importing Equality? The Impact of Globalization } \\
\text { on Gender Discrimination }\end{array}$ & 1 & $08 / 02$ \\
\hline 557 & $\begin{array}{l}\text { G. C. Giannelli } \\
\text { C. Braschi }\end{array}$ & $\begin{array}{l}\text { Reducing Hours of Work: Does Overtime Act as } \\
\text { a Brake Upon Employment Growth? An Analysis } \\
\text { by Gender for the Case of Italy }\end{array}$ & 5 & $08 / 02$ \\
\hline 558 & $\begin{array}{l}\text { T. Bauer } \\
\text { G. Epstein } \\
\text { I. N. Gang }\end{array}$ & $\begin{array}{l}\text { Enclaves, Language and the Location Choice of } \\
\text { Migrants }\end{array}$ & 1 & $08 / 02$ \\
\hline 559 & $\begin{array}{l}\text { B. R. Chiswick } \\
\text { T. J. Hatton }\end{array}$ & $\begin{array}{l}\text { International Migration and the Integration of } \\
\text { Labor Markets }\end{array}$ & 2 & $08 / 02$ \\
\hline 560 & $\begin{array}{l}\text { J. W. Budd } \\
\text { J. Konings } \\
\text { M. J. Slaughter }\end{array}$ & $\begin{array}{l}\text { Wages and International Rent Sharing in } \\
\text { Multinational Firms }\end{array}$ & 2 & $08 / 02$ \\
\hline 561 & $\begin{array}{l}\text { W. J. Carrington } \\
\text { P. R. Mueser } \\
\text { K. R. Troske }\end{array}$ & $\begin{array}{l}\text { The Impact of Welfare Reform on Leaver } \\
\text { Characteristics, Employment and Recidivism }\end{array}$ & 3 & $08 / 02$ \\
\hline 562 & $\begin{array}{l}\text { J. T. Addison } \\
\text { W. S. Siebert }\end{array}$ & Changes in Collective Bargaining in the U.K. & 3 & $08 / 02$ \\
\hline
\end{tabular}

W. S. Siebert

An updated list of IZA Discussion Papers is available on the center's homepage www.iza.org. 